Article

\title{
Upscaling Gross Primary Production in Corn-Soybean Rotation Systems in the Midwest
}

\author{
Christian Dold ${ }^{1} * \mathbb{1}$, Jerry L. Hatfield ${ }^{1}{ }^{\circledR}$, John H. Prueger ${ }^{1}$, Tom B. Moorman ${ }^{1}$, Tom J. Sauer ${ }^{1}$, \\ Michael H. $\operatorname{Cosh}^{2}$, Darren T. Drewry ${ }^{3}$ iD and Ken M. Wacha ${ }^{1}$ (D) \\ 1 USDA-ARS, National Laboratory for Agriculture and the Environment, Ames, IA 50011, USA \\ 2 USDA-ARS, Hydrology and Remote Sensing Laboratory, BARC-West, Beltsville, MD 20705, USA \\ 3 Department of Food, Agricultural and Biological Engineering, The Ohio State University, \\ Columbus, $\mathrm{OH} 43210$, USA \\ * Correspondence: christian.dold@ars.usda.gov
}

Received: 29 May 2019; Accepted: 13 July 2019; Published: 17 July 2019

\begin{abstract}
The Midwestern US is dominated by corn (Zea mays L.) and soybean (Glycine max [L.] Merr.) production, and the carbon dynamics of this region are dominated by these production systems. An accurate regional estimate of gross primary production (GPP) is imperative and requires upscaling approaches. The aim of this study was to upscale corn and soybean GPP

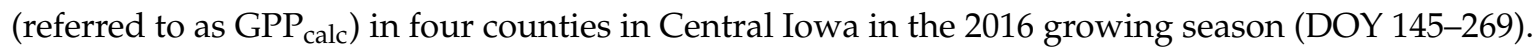
Eight eddy-covariance (EC) stations recorded carbon dioxide fluxes of corn $(n=4)$ and soybean $(\mathrm{n}=4)$, and net ecosystem production (NEP) was partitioned into GPP and ecosystem respiration (RE). Additional field-measured NDVI was used to calculate radiation use efficiency (RUE $\mathrm{max}_{\text {ma }}$ ). GPP $\mathrm{Palc}_{\text {cal }}$ was calculated using 16 MODIS satellite images, ground-based $\mathrm{RUE}_{\max }$ and meteorological data, and improved land use maps. Seasonal NEP, GPP, and RE ( $\bar{x} \pm$ SE) were $678 \pm 63,1483 \pm 100$, and $-805 \pm 40 \mathrm{~g} \mathrm{C} \mathrm{m}^{-2}$ for corn, and $263 \pm 40,811 \pm 53$, and $-548 \pm 14 \mathrm{~g} \mathrm{C} \mathrm{m}^{-2}$ for soybean, respectively. Field-measured NDVI aligned well with MODIS fPAR $\left(R^{2}=0.99\right)$, and the calculated RUE $E_{\max }$ was

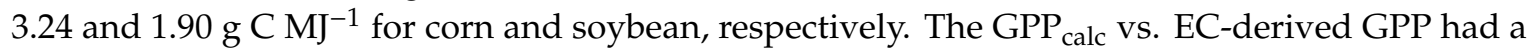
RMSE of 2.24 and $2.81 \mathrm{~g} \mathrm{C} \mathrm{m}^{-2} \mathrm{~d}^{-1}$, for corn and soybean, respectively, which is an improvement to the GPP MODIs product (2.44 and $3.30 \mathrm{~g} \mathrm{C} \mathrm{m}^{-2} \mathrm{~d}^{-1}$, respectively). Corn yield, calculated from GPP calc $\left(12.82 \pm 0.65 \mathrm{Mg} \mathrm{ha}^{-1}\right)$, corresponded well to official yield data $\left(13.09 \pm 0.09 \mathrm{Mg} \mathrm{ha}^{-1}\right)$, while soybean yield was overestimated $\left(6.73 \pm 0.27 \mathrm{vs} .4 .03 \pm 0.04 \mathrm{Mg} \mathrm{ha}^{-1}\right)$. The approach presented has the potential to increase the accuracy of regional corn and soybean GPP and grain yield estimates by integrating field-based flux estimates with remote sensing reflectance observations and high-resolution land use maps.
\end{abstract}

Keywords: ACPF; eddy covariance; MODIS fPAR; NDVI; radiation use efficiency

\section{Introduction}

Midwestern US agriculture is dominated by corn (Zea mays L.) and soybean (Glycine max [L.] Merr.) production and both crops are important export commodities. In 2017, corn and soybean production in the United States made up 33\% and 34\% of total world production, and $56 \%$ and $46 \%$ of US production came from the Corn Belt states (Iowa, Nebraska, Indiana, Illinois, and Kansas), respectively [1,2]. Vast agricultural areas are used in the production of these crops which can impact gross primary production (GPP) and the global carbon cycle. The Midwestern US region was found to have one of the highest GPP rates in the northern hemisphere, owing to the large-scale production of corn, a C4 crop [3]. In addition, conventional corn and soybean production with bare soil in the off-season and frequent tillage events can impact GPP compared to reduced till systems [4]. Despite recent improvements in 
crop and soil management, no-till and cover crop systems only make up 35\% and 4\% in Iowa in 2017, respectively, meaning that conventional systems are prevailing [5]. Due to the economic and ecological importance of this region, the quantification of regional GPP as a proxy for yield as well as an essential part of the carbon cycle, remains imperative. The improvement of GPP estimations on a regional scale may also help to assess how changes in crop and soil management impact GPP and yield over time and may be used as decision support tool for climate-smart agriculture and best-practice management in terms of carbon cycling, soil quality, and crop performance.

There have been different approaches to quantify GPP from satellite images, such as the MODerate resolution Imaging Spectroradiometer (MODIS) satellite GPP product (MOD17A2) (referred to as $\mathrm{GPP}_{\text {MODIS }}$; however, the accuracy of these estimates has been limited to a regional scale [6,7]. Therefore,

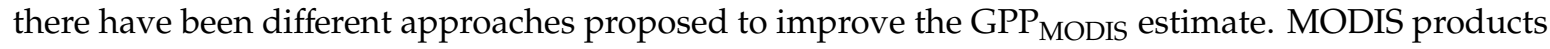
have been included in a biophysical model to calculate GPP on a global level, which showed good agreement to eddy covariance (EC) derived GPP [8,9]. Another modelling approach using MODIS imagery products could also improve GPP measurements in a Douglas fir stand [10]. Other models have been proposed in literature to ameliorate GPP MODIS [11]. A more parsimonious approach is the improvement of the maximum radiation use efficiency ( $R E_{\max }$ ) and the fraction of absorbed photosynthetic active radiation (fPAR) estimates with field measurements and EC-derived GPP, as well

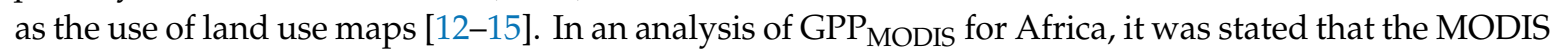
biome parameters need further improvement [16]. This is also true for other biomes worldwide [17]. Accordingly, new input parameters were used to up-scale GPP from field to whole regions in the Midwestern US using MODIS products [12,13]. However, previous studies in the Midwestern US were either constrained by the density of ground-based EC stations (i.e., number of EC stations per area), or by the lack of field-based measurements of RUEmax or fPAR [12,13]. In addition, new land use maps were developed to distinguish crop fields with higher accuracy [18]. The aim of this study was to up-scale GPP with MODIS satellite image products from field to county using eight EC stations distributed across four counties in Iowa, additional field-based canopy reflectance measurements, and improved land use maps for the growing season of 2016. Therefore, crop-specific RUEmax were calculated, and GPP products evaluated.

\section{Material and Methods}

\subsection{Study Sites}

The study was conducted as part of the Soil Moisture Active Passive Validation Experiment in 2016 (SMAPVEX16) during the growing season (i.e., day of year (DOY) 145-269; total: 125 days) in four neighboring counties in North Central Iowa: Story, Franklin, Hamilton, and Hardin County [19,20]. The overall experiment was dedicated to exploring the land surface soil moisture conditions across a homogeneous landscape to improve vegetation characterization and soil moisture remote sensing algorithms via the Soil Moisture Active Passive Mission. Within each county, two field sites under a corn-soybean rotation, one each planted in corn and the other in soybeans (Figure 1). The sites are located on the Des Moines Lobe and soils belong to the Clarion-Nicollet-Webster association [21]. The site characteristics are summarized in Table 1 . The sites reflect well the dominating crop and soil management conditions of the four counties, with $98 \%$ of the harvested cropland used for corn and soybean production, and only 13\% of the cropped area under no-till and 3\% planted with cover crops [5]. In terms of climatic parameters, the 30-year (1986-2016) minimum and maximum temperature between June and September averaged $( \pm$ SE) over four nearby weather stations was $15.38 \pm 0.16$ and $26.94 \pm 0.08{ }^{\circ} \mathrm{C}$. All agricultural sites are rain-fed systems with a seasonal 30-year precipitation of $508 \pm 17 \mathrm{~mm}[22]$. 


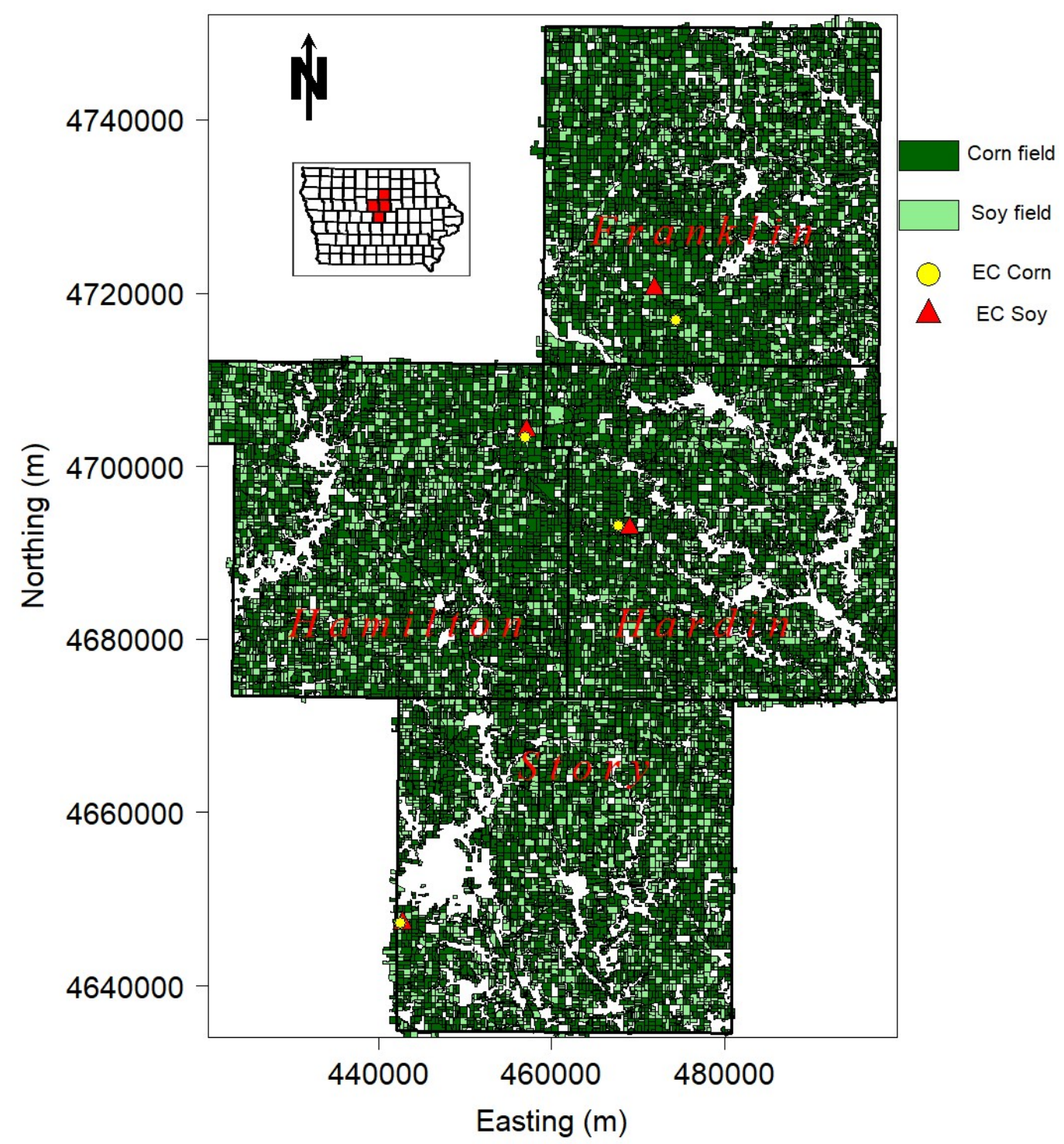

Figure 1. Land use map of four counties in Iowa (red marked counties in small map) in 2016 [18]: Story County (lower), Hamilton County (center left), Hardin County (center right), and Franklin County (upper). Corn fields are marked dark green, and soybean fields are light green (each land use area > $55 \%$ ). The red triangles and yellow circles show the location of the eddy-covariance (EC) stations in soybean and corn fields, respectively. 
Table 1. Site specifics (location, soils, crop management) and EC station instrumentation (sonic, IRGA, and radiation specifics, measurement height, measurement frequency, and sonic direction).

\begin{tabular}{|c|c|c|c|c|c|c|c|c|}
\hline \multirow{2}{*}{$\frac{\text { County }}{\text { Ameriflux code }}$} & \multicolumn{2}{|c|}{ Story } & \multicolumn{2}{|c|}{ Franklin } & \multicolumn{2}{|c|}{ Hamilton } & \multicolumn{2}{|c|}{ Hardin } \\
\hline & US-Br1 & US-Br3 & - & - & - & - & - & - \\
\hline Crop & Corn & Soybean & Corn & Soybean & Corn & Soybean & Corn & Soybean \\
\hline $\begin{array}{c}\text { Latitude, } \\
\text { Longitude (dec. }^{\circ} \text { ) }\end{array}$ & $41.975,-93.694$ & $41.975,-93.691$ & $42.603,-93.313$ & $42.637,-93.343$ & $42.482,-93.524$ & $42.488,-93.523$ & $42.390,-93.392$ & $42.387,-93.377$ \\
\hline Field size (ha) & 31.5 & 25.8 & 119.2 & 94.1 & 47.5 & 60.8 & 28.8 & 44.0 \\
\hline Soil type and texture ${ }^{1}$ & \multicolumn{2}{|c|}{$\begin{array}{l}\text { Canisteo, Harps, Okoboji, } \\
\text { loam-clay loam }\end{array}$} & \multicolumn{2}{|c|}{$\begin{array}{l}\text { Harps, Okoboji, Zenor, Storden, } \\
\text { Salida, Coland, Lawler } \\
\text { sandy loam-clay loam }\end{array}$} & \multicolumn{2}{|c|}{$\begin{array}{l}\text { Harps, Okoboji } \\
\text { loam-clay loam }\end{array}$} & \multicolumn{2}{|c|}{$\begin{array}{c}\text { Storden, Okoboji, Harps, Coland } \\
\text { loam-clay loam }\end{array}$} \\
\hline Soil management & $\begin{array}{l}\text { Spring tillage; } \\
\text { fall tillage }\end{array}$ & Spring tillage & $\begin{array}{l}\text { Spring tillage; } \\
\text { fall tillage }\end{array}$ & Spring tillage & Spring tillage & NA & No data & No data \\
\hline $\begin{array}{c}\text { N-rate } \\
\left(\mathrm{kg} \mathrm{N} \mathrm{ha}^{-1} \text { year }^{-1}\right)\end{array}$ & $\begin{array}{l}\text { Anhydrous-N: } \\
168\end{array}$ & NA & No data & No data & $\mathrm{NH}_{3} / \mathrm{UAN}: 157$ & NA & No data & No data \\
\hline Density (plants ha ${ }^{-1}$ ) & 80,000 & 379,000 & 83,200 & 309,000 & 78,600 & 323,000 & 92,900 & No data \\
\hline Planting-Harvest DOY & $111-271$ & $128-292$ & $140-271$ & $144-270$ & $128-273$ & $115-282$ & $138-298$ & $144-275$ \\
\hline IRGA model & \multicolumn{2}{|c|}{ LI-7500 ${ }^{2}$} & \multicolumn{2}{|c|}{$\mathrm{EC} 150^{3}$} & \multicolumn{2}{|c|}{ IRGASON $^{3}$} & \multicolumn{2}{|c|}{ LI-7500 ${ }^{2}$} \\
\hline $\begin{array}{l}\text { 3-D Sonic anemometer } \\
\text { model }\end{array}$ & \multicolumn{2}{|c|}{ CSAT $-3^{3}$} & \multicolumn{2}{|c|}{$\mathrm{EC} 150^{3}$} & \multicolumn{2}{|c|}{ IRGASON $^{3}$} & \multicolumn{2}{|c|}{ CSAT $-3^{3}$} \\
\hline $\mathrm{z}_{\mathrm{m}}(\mathrm{cm})$ & $240-500$ & 225 & $200-500$ & 200 & $200-500$ & $200-240$ & $200-500$ & $218-240$ \\
\hline Frequency $(\mathrm{Hz})$ & \multicolumn{8}{|c|}{20} \\
\hline $\begin{array}{l}\text { Azimuth } \\
\text { from North }\end{array}$ & \multicolumn{8}{|c|}{$270^{\circ}$} \\
\hline $\begin{array}{c}\text { Radiation } \\
\text { sensor model }\end{array}$ & \multicolumn{2}{|c|}{ CNR-1 ${ }^{4}$} & \multicolumn{2}{|c|}{ CNR-4 4} & \multicolumn{2}{|c|}{ NR-01 5} & \multicolumn{2}{|c|}{ CNR-1 4} \\
\hline
\end{tabular}

Sonic $=3$-D sonic anemometer, IRGA $=$ infrared gas analyzer, $\mathrm{z}_{\mathrm{m}}=$ measurement height. ${ }^{1}$ retrieved from soil descriptions [14]. ${ }^{2}$ LICOR Biosciences Inc., Lincoln, NE, USA. ${ }^{3}$ Campbell Scientific, Inc., Logan, UT, USA. ${ }^{4}$ Kipp \& Zonen, Delft, The Netherlands. ${ }^{5}$ Hukseflux, Delft, The Netherlands 


\subsection{Eddy Covariance Datasets}

Turbulent fluxes of carbon dioxide $\left(\mathrm{F}_{\mathrm{c}}\right)$ were computed at each site $(\mathrm{n}=8 \mathrm{EC}$ stations) using the EC method [23]. One EC station was deployed in each field, so that the EC footprint covered the crop of interest in a representative portion of the field and in the main wind direction. The $90 \%$ footprint of each EC station was calculated [24], and mean ( \pm SD) flux footprint area was $4.4 \pm 2.3$ ha (Figure A1). The $90 \%$ footprint area at the corn-site in Franklin County surpassed the field, and the footprint was cropped to field boundaries. Note that most of the information recorded by the sensor is from nearby the EC station and not from the edges of the footprint. Also, the footprint area is an average of the entire season including day- and nighttime data, with higher fetch during night than during the day. An open-path infrared gas analyzer (IRGA) measured carbon dioxide and water density. Instantaneous high frequency sonic temperature and wind speed velocity components were measured with a 3-D sonic anemometer. The measurement height of IRGAs and sonic anemometers ranged between 200 and $500 \mathrm{~cm}$, depending on crop height during the season. The $\mathrm{F}_{\mathrm{c}}$ were computed as the covariance between the instantaneous vertical wind velocity and carbon dioxide density. The $\mathrm{F}_{\mathrm{c}}$ was coordinate rotated [25] and corrected for temperature and air density variations [26]. The EC sampling rate (high frequency) was $20 \mathrm{~Hz}$ and was averaged to a 15-min time interval. Sonic and IRGA models and manufacturers are presented in Table 1.

A net radiometer measured incoming shortwave radiation (Table 1). An air temperature and humidity probe measured ambient air temperature (Ta) and relative humidity ( $\mathrm{rH}$ ) (Vaisala HMP45c, Vantaa, Finland). Precipitation was recorded using tipping bucket rain gauges (Model TR525 USW, Texas Electronics, Dallas, TX, USA). Soil moisture content was measured at $10 \mathrm{~cm}$ depth with soil moisture probes (Hydra Probe, Stevens Water Monitoring Systems, Portland, OR, USA). Thermocouples were buried at 2 and $6 \mathrm{~cm}$ to measure soil temperature, and heat flux plates (HFT-1, Radiation Energy Balance, Seattle, WA, USA) measured soil heat flux at $6 \mathrm{~cm}$ soil depth. An infrared temperature sensor (IRR, Apogee Instruments Inc., Logan, UT, USA) measured surface temperature and mounted at $45^{\circ}$ from perpendicular. The ancillary instrumentation was sampled at $0.1 \mathrm{~Hz}$ and averaged on a 15-min interval. The data were recorded on data loggers (CR5000, Campbell Scientific, Logan, UT). Further specifications of the EC systems are listed in Table 1.

\subsection{Outlier Detection and Interpolation}

The EC data were screened for statistical outliers and sensor failures and thereafter interpolated to fill data gaps [27]. Data was excluded under unfavorable weather conditions, such as during rain events, low wind turbulence and wind directions opposite to the sonic sensor direction [28], and time periods with high $\mathrm{rH}$ [29]. The internal sonic and IRGA warning flags and automated gain control were used to identify low-quality data. Data were screened for outliers using empirical set limits and the interquartile range (IQR) procedure, where outliers were defined as 1st/3rd Quartile \pm 3.5 * IQR. Then the data were interpolated with an inverse weighted time average procedure [30]. The $\mathrm{F}_{\mathrm{C}}$ was separated for day- and nighttime $\left(\mathrm{F}_{\mathrm{c} \text { day }}, \mathrm{F}_{\mathrm{c} \text { night }}\right)$ and $\mathrm{F}_{\mathrm{c} \text { night }}$ (i.e., nighttime respiration) was interpolated using the relationship between air temperature and $\mathrm{CO}_{2}$ fluxes [31], while $\mathrm{F}_{\mathrm{c}}$ day was gap filled with daily light response curves [32]. Approximately $31 \%-55 \%$ of the $15-\mathrm{min} \mathrm{F}_{\mathrm{c}}$ data was excluded, and $\mathrm{F}_{\mathrm{c} \text { night }}$ was more affected than $\mathrm{F}_{\mathrm{c} \text { day }}$. Approximately $29 \%-42 \%$ of the $\mathrm{F}_{\mathrm{c}}$ data was interpolated. Daily values were calculated as the daily average multiplied by the number of samples per day.

Daily net ecosystem production (NEP) was calculated as the sum of daily $\mathrm{F}_{\mathrm{c}}$ day and $\mathrm{F}_{\mathrm{c} \text { night }}$. Here the arithmetic sign convention is positive for $F_{c}$ from the atmosphere to the surface. The NEP was partitioned into GPP and RE. The GPP was calculated as the difference between NEP and RE. Daily RE was calculated as the sum of $F_{c \text { night }}$ and daytime respiration $(R d)$. $R d$ was derived from the non-linear 
relationship between incoming photosynthetic active radiation (IPAR) and $\mathrm{F}_{\mathrm{c} \text { day }}$ using light response curves, such as the rectangular hyperbola function [32]:

$$
F_{c \text { day }}=\frac{A Q Y * I P A R * P_{g \text { max }}}{P_{g \text { max }}+A Q Y * I P A R}-R d
$$

where: $\mathrm{F}_{\mathrm{c} \text { day }}=$ daytime $\mathrm{CO}_{2}$ flux $\left(\mu \mathrm{mol} \mathrm{m} \mathrm{m}^{-2} \mathrm{~s}^{-1}\right) ; \mathrm{AQY}=$ apparent quantum yield $\left(\mu \mathrm{mol} \mathrm{CO}_{2} \mu \mathrm{mol}\right.$ $\left.\mathrm{PAR}^{-1}\right), \mathrm{P}_{\mathrm{g} \max }=$ maximum gross photosynthesis rate $\left(\mu \mathrm{mol} \mathrm{CO} \mathrm{Cm}^{-2} \mathrm{~s}^{-1}\right) ; \mathrm{IPAR}=$ photosynthetic active radiation $\left(\mu \mathrm{mol} \mathrm{m} \mathrm{m}^{-2} \mathrm{~s}^{-1}\right)$; $\mathrm{Rd}=$ mean daytime respiration $\left(\mu \mathrm{mol} \mathrm{CO} \mathrm{Cm}^{-2} \mathrm{~s}^{-1}\right)$.

IPAR was assumed to be $45 \%$ of incoming shortwave radiation [5] and was converted to photon flux density with $1 \mathrm{~W} \mathrm{~m}^{-2}=4.6 \mu \mathrm{mol} \mathrm{m}^{-2} \mathrm{~s}^{-1}$ [33].

Daily NEP, RE, GPP and Rd values were screened again for outliers and interpolated using the inverse weighted time average procedure. Seasonal values were calculated as seasonal averages multiplied with number of days.

\subsection{NDVI Ground-Based Measurements}

Reflectance data on the ground were measured with a radiometer (CropScan, CROPSCAN, Inc., Rochester, MN, USA) in the corn and soybean field in Story County during the 2016 growing season. A total of 33 and 31 measurements were made on soybean and corn, respectively, in observation intervals of 2-14 days between DOY 124 and 308. Measurements were constrained to clear-sky conditions or with little cirrus clouds and with sun angles $>45^{\circ}$ (i.e., 10.00 and 14.00 CST). The radiometer measured reflected and incoming radiation at 16 wavebands between 460 and $1700 \mathrm{~nm}$. Each measurement consisted of 30 individual scans, and an average is calculated by the unit. Measurements were taken above the crop at five locations north of the EC stations, and the measurement height was adjusted to yield a surface pixel size of $1.5 \mathrm{~m}$. The radiometer was calibrated with a reflectance panel and a dark measurement prior to field observations. The Normalized Difference Vegetation Index (NDVI) was calculated as:

$$
N D V I=\frac{\rho_{760}-\rho_{660}}{\rho_{760}+\rho_{660}}
$$

where: $\rho_{660}$ and $\rho_{760}$ were the surface reflectance of the red $(660 \mathrm{~nm})$ and near-infrared $(760 \mathrm{~nm})$ wavelength bands, respectively.

The individual observations at each location were averaged, and the averaged values interpolated with an inverse weighted time average procedure to yield a daily NDVI dataset for the 2016 growing season. Further information on CropScan measurements can be found in literature [34,35]. In addition to NDVI measurement, plant development and plant height was recorded ( $\operatorname{corn} n=21$, soybean $n=40$ ). The development stages are categorized in vegetative and reproductive growth as $\mathrm{V}$ and $\mathrm{R}$ Stages, respectively. The V-Stages in corn categorize plant emergence (VE), number of fully developed leaves (e.g., V1 for first leaf) and tasseling (VT), while the six R-Stages categorize corn flowering (R1), and ear development (R2-5) until maturation and senescence (R6) [36]. The V-stages in soybean categorize plant emergence (VE), first unifoliate leaf (VC), and number of fully developed trifoliate leaves on the main stem. In contrast to corn, reproductive stages occur during plant growth (V-stages), and categorize flowering (R1-2), pod development (R3-6), and maturation and senescence (R7-8) [37]. Plant height was measured from the ground to the top of the canopy, and daily height was calculated by fitting a three-parameter sigmoidal model. Due to resource restrictions, NDVI and intensive crop measurements were limited to the site in Story County.

\subsection{MODIS fPAR Products, and Land Use Maps}

The fraction of absorbed IPAR (400-700 nm wavelength), fPAR, can be derived from MODIS satellite images, and MODIS fPAR products (MCD15A2H) were provided by the U.S. Geological Survey $[38,39]$. The MODIS fPAR product had a resolution of $500 \times 500 \mathrm{~m}$ and images are available at an 8-day interval. In total, 16 fPAR scenes between DOY 145 and 265 for the North Central Iowa 
counties were obtained. The quality of the fPAR scenes was checked with the $\mathrm{Q} / \mathrm{C}$ layers provided by USGS, and areas of low quality were excluded.

The fPAR scenes were cropped to the $90 \%$ footprint area (i.e., two to four data points) of each EC station, as well as for the corn and soybean fields in each county. Corn and soybean fields were identified using the 2016 county land use maps (Figure 1) provided by the Agricultural Conservation Planning Framework (ACPF) [18]. Only fields with a land use area $>55 \%$ designated for corn and soybean production were used.

\subsection{GPP Upscaling and Radiation Use Efficiency}

The 8-day GPP MODIS product from MODIS satellite imagery (MOD17A2H) is calculated as [6]:

$$
G P P_{M O D I S}=R U E_{\text {max }} * \operatorname{Tmin}_{S} * V P D_{S} * f P A R * I P A R
$$

where: $\mathrm{GPP}_{\text {MODIS }}=$ MODIS gross primary production product $\left(\mathrm{g} \mathrm{C} \mathrm{m}^{-2} 8\right.$-day $\left.{ }^{-1}\right), \mathrm{RUE}_{\max }=$ maximum radiation use efficiency $\left(\mathrm{g} \mathrm{C} \mathrm{MJ}^{-1}\right), \mathrm{Tmin}_{\mathrm{s}}=\mathrm{a}$ temperature scalar (no units), $\mathrm{VPD}_{\mathrm{s}}=\mathrm{a}$ vapor pressure deficit scalar (no units), fPAR = fraction of IPAR absorbed by the crop (no units), IPAR = incoming photosynthetic active radiation $\left(\mathrm{MJ} \mathrm{m}^{-2} \mathrm{~d}^{-1}\right)$.

Note that the GPP ${ }_{\text {MODIS }}$ is calculated as 8-day sums, and daily values can only be calculated as daily means (Appendix B). The scalars $\mathrm{Tmin}_{\mathrm{s}}$ and $\mathrm{VPD}_{\mathrm{s}}$ are proxies for $\mathrm{RUE}_{\max }$ limitations of temperature and vapor pressure deficit (VPD), respectively. The scalars $\mathrm{Tmin}_{\mathrm{s}}$ and $\mathrm{VPD}_{\mathrm{s}}$ are calculated as [6]:

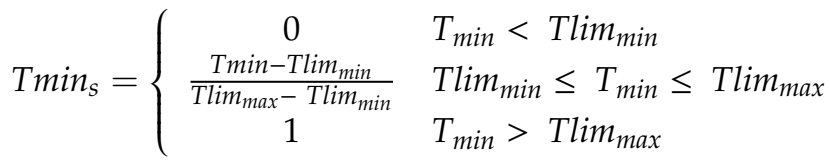

$$
\begin{aligned}
& V P D_{s}\left\{\begin{array}{cl}
0 & V P D>V P D_{\text {max }} \\
1-\frac{V P D-V P D_{\min }}{V P D_{\max }-V P D_{\min }} & V P D_{\text {min }} \leq V P D \leq V P D_{\text {msx }} \\
1 & V P D<V P D_{\text {min }}
\end{array}\right.
\end{aligned}
$$

where: $\operatorname{Tmin}_{\mathrm{s}}=$ scalar for daily Tmin (no units), $\operatorname{Tmin}=$ daily minimum $\mathrm{Ta}\left({ }^{\circ} \mathrm{C}\right), \operatorname{Tlim}_{\min }=$ lower $\operatorname{Tmin}$ limit $\left({ }^{\circ} \mathrm{C}\right), \mathrm{Tlim}_{\max }=$ upper Tmin limit $\left({ }^{\circ} \mathrm{C}\right), \mathrm{VPDs}=$ scalar for daytime VPD (no units), $\mathrm{VPD}=$ average daytime vapor pressure deficit $(\mathrm{kPa}), \mathrm{VPD}_{\min }=$ lower $\mathrm{VPD}$ limit $(\mathrm{kPa}), \mathrm{VPD}_{\max }=$ upper VPD limit $(\mathrm{kPa})$.

The $\mathrm{Tlim}_{\min }$ and $\mathrm{Tlim}_{\max }$ are set to -8 and $12.02^{\circ} \mathrm{C}$, while $\mathrm{VPD}_{\min }$ and $\mathrm{VPD}_{\max }$ are set to 0.65 and $4.3 \mathrm{kPa}$, respectively [6].

The GPP was upscaled from field to county following the same concept in Equation (3) (referred to as $\mathrm{GPP}_{\text {calc }}$ ). First, RUE $\mathrm{max}_{\max }$ for corn and soybean was calculated using the EC station data and NDVI field measurements from the Story County site. Equation (3) was solved for RUE $\mathrm{max}_{\text {ax }}$ and fPAR substituted with field-measured corn and soybean NDVI, assuming that fPAR $\approx$ NDVI [6]. The VPD was calculated as the difference between saturated $\left(e_{s}\right)$ and actual vapor pressure $\left(e_{a}\right)$, of which the former was calculated as a function of Ta [40], and the latter as $\mathrm{e}_{\mathrm{s}}$ multiplied with $\mathrm{rH}$. Then $\mathrm{VPD}_{\mathrm{s}}$ and $\mathrm{Tlim}_{\mathrm{s}}$ were calculated. RUE $E_{\max }$ was calculated as the slope of a linear regression $(\mathrm{p}<0.05)$ with the product of $\mathrm{Tlim}_{\mathrm{s}}, \mathrm{VPD}_{\mathrm{s}}, \mathrm{NDVI}$ and IPAR as independent variable and EC-derived GPP as dependent variable [7]. At last, GPP calc was upscaled for the whole county using Equation (3), with MODIS fPAR products cropped for county-wide corn and soybean fields, respectively, and crop-specific RUE $E_{\max }$. $\mathrm{GPP}_{\text {calc }}$ was set to zero when fPAR $<0.4$ (see Section 4).

\subsection{Data Preparation, and Statistical Analysis}

The variation of corn and soybean GPP among EC stations was quantified by calculating the $95 \%$ confidence intervals $(\mathrm{CI})$ using the bootstrap percentile method with two thousand replications. Bootstrapping was run with the boot package in R [41]. Relationships between NEP, GPP, RE and 
climate parameters were evaluated with Pearson correlation and the regression coefficient ( $\mathrm{r}$ ) was calculated. The ACPF land use maps were validated with the 2016 county-wide corn and soybean production area [1] using linear regression analysis $(\mathrm{p}<0.05)$ and cross-checked with the MODIS land cover type product (MCD12Q1) from 2016 [38,42]. The median EC-footprint and county-wide

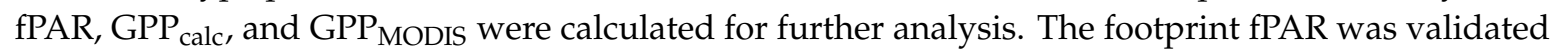
against field-measured NDVI with linear regression analysis $(\mathrm{p}<0.05) . \mathrm{GPP}_{\text {calc }}$ was validated against EC-derived GPP using a linear regression analysis $(\mathrm{p}<0.05)$ and was also compared to the GPP MODIS product $[5,38]$. The median county-wide $\mathrm{GPP}_{\text {calc }}$ was interpolated with an inverse weighted time average procedure to produce a daily dataset, and grain yield was calculated $[7,12]$ as:

$$
\text { Yield }_{G P P}=\frac{G P P_{\text {calc }} * \frac{H I}{(1+R S)} * \frac{1}{(1-M)}}{O C}
$$

where: Yield $_{\mathrm{GPP}}=$ calculated yield data $\left(\mathrm{Mg}\right.$ dry weight ha $\left.{ }^{-1}\right), \mathrm{GPP}_{\text {calc }}=$ seasonal sum of daily median county $\mathrm{GPP}_{\text {calc }}\left(\mathrm{g} \mathrm{C} \mathrm{m}^{-2}\right), \mathrm{HI}=$ Harvest index, $\mathrm{RS}=$ root-shoot ratio, $\mathrm{M}=\%$ moisture content, $\mathrm{OC}=\%$ grain carbon content.

The HI was set to 0.50 and 0.57 [43,44], the RS was 0.18 and 0.15 [45], M was $15.5 \%$ and $13 \%$, and OC was $44.7 \%$ and $54 \%$ [46], for corn and soybean, respectively. The Yield ${ }_{\mathrm{GPP}}$ was compared to the 2016 county yield data [1]. All figures were created with the R programming language [41].

\section{Results}

\subsection{Eddy-Flux Station Data}

Eight EC stations measured carbon fluxes and meteorological data in fields with corn-soybean rotation during the growing season 2016. Mean daily IPAR decreased from $8.98 \mathrm{MJ} \mathrm{m}^{-2}$ on DOY 159 to $1.02 \mathrm{MJ} \mathrm{m}^{-2}$ on DOY 253 (Figure 2A). Mean Ta ranged from 16.4 and $28.8^{\circ} \mathrm{C}$ (Figure 2B) and mean $( \pm$ SE) seasonal precipitation was $515 \pm 51 \mathrm{~mm}$, which is warmer and with near normal rainfall compared to the 30-year seasonal average (see Section 2.1). The average daytime VPD ranged between $0.13-2.40 \mathrm{kPa}$ (Figure 2C).

Maximum average corn GPP $\left( \pm\right.$ SE) was reached at DOY 196 with $26.0 \pm 3.2 \mathrm{~g} \mathrm{C} \mathrm{m}^{-2} \mathrm{~d}^{-1}$, and maximum average soybean GPP was reached at DOY 218 with $13.7 \pm 2.3 \mathrm{~g} \mathrm{C} \mathrm{m}^{-2} \mathrm{~d}^{-1}$ (Figure 2D). Seasonal corn and soybean GPP were $1483 \pm 100$ and $811 \pm 53 \mathrm{~g} \mathrm{C} \mathrm{m}^{-2}$, respectively (Table 2). Mean corn NEP ranged from -3.6 to $17.1 \mathrm{~g} \mathrm{C} \mathrm{m}^{-2} \mathrm{~d}^{-1}$ (Figure 2E), with a site-average ( $\pm \mathrm{SE}$ ) seasonal total of $678 \pm 63 \mathrm{~g} \mathrm{C} \mathrm{m}^{-2}$ (Table 2). The 95\% CI are presented in Table 2. Cumulative corn NEP was greater than zero (i.e., carbon uptake $>$ respiration) starting from DOY 169. Mean soybean NEP ranged from -3.7 to $7.8 \mathrm{~g} \mathrm{C} \mathrm{m}^{-2} \mathrm{~d}^{-1}$ (Figure 2E), with a seasonal NEP of $263 \pm 40 \mathrm{~g} \mathrm{C} \mathrm{m}^{-2}$ (Table 2). Cumulative seasonal soybean NEP surpassed zero from DOY 181. Minimum corn RE (i.e., highest respiration) was reached at DOY 204 with $-11.6 \mathrm{~g} \mathrm{C} \mathrm{m}^{-2} \mathrm{~d}^{-1}$, and maximum corn RE at DOY 237 with $-1.6 \mathrm{~g} \mathrm{C}$ $\mathrm{m}^{-2} \mathrm{~d}^{-1}$ (Figure 2F). Minimum soybean RE was at DOY 160 with $-7.1 \mathrm{~g} \mathrm{C} \mathrm{m}^{-2} \mathrm{~d}^{-1}$, and maximum soybean RE at DOY 217 with $-1.2 \mathrm{~g} \mathrm{C} \mathrm{m}^{-2} \mathrm{~d}^{-1}$. Seasonal corn and soybean RE were $-805 \pm 40$ and $-548 \pm 14 \mathrm{~g} \mathrm{C} \mathrm{m}^{-2}$, respectively (Table 2). NEP, RE, and GPP followed the seasonal and daily pattern of Ta, IPAR, and VPD (Figure 2). The site-specific daily NEP was weakly correlated to IPAR $(r=0.20-0.54)$, daytime VPD $(r=0.02-0.41)$, and Tmin $(r=-0.01-0.21)$. Daily GPP was weakly correlated to IPAR $(\mathrm{r}=0.11-0.45)$, daytime VPD $(\mathrm{r}=0.02-0.47)$, and Tmin $(\mathrm{r}=0.07-0.31)$ as well. Also, daily RE was weakly correlated to IPAR $(r=-0.18-0.20)$, daytime VPD $(r=0.02-0.48)$, and Tmin $(r=0.22-0.42)$. 

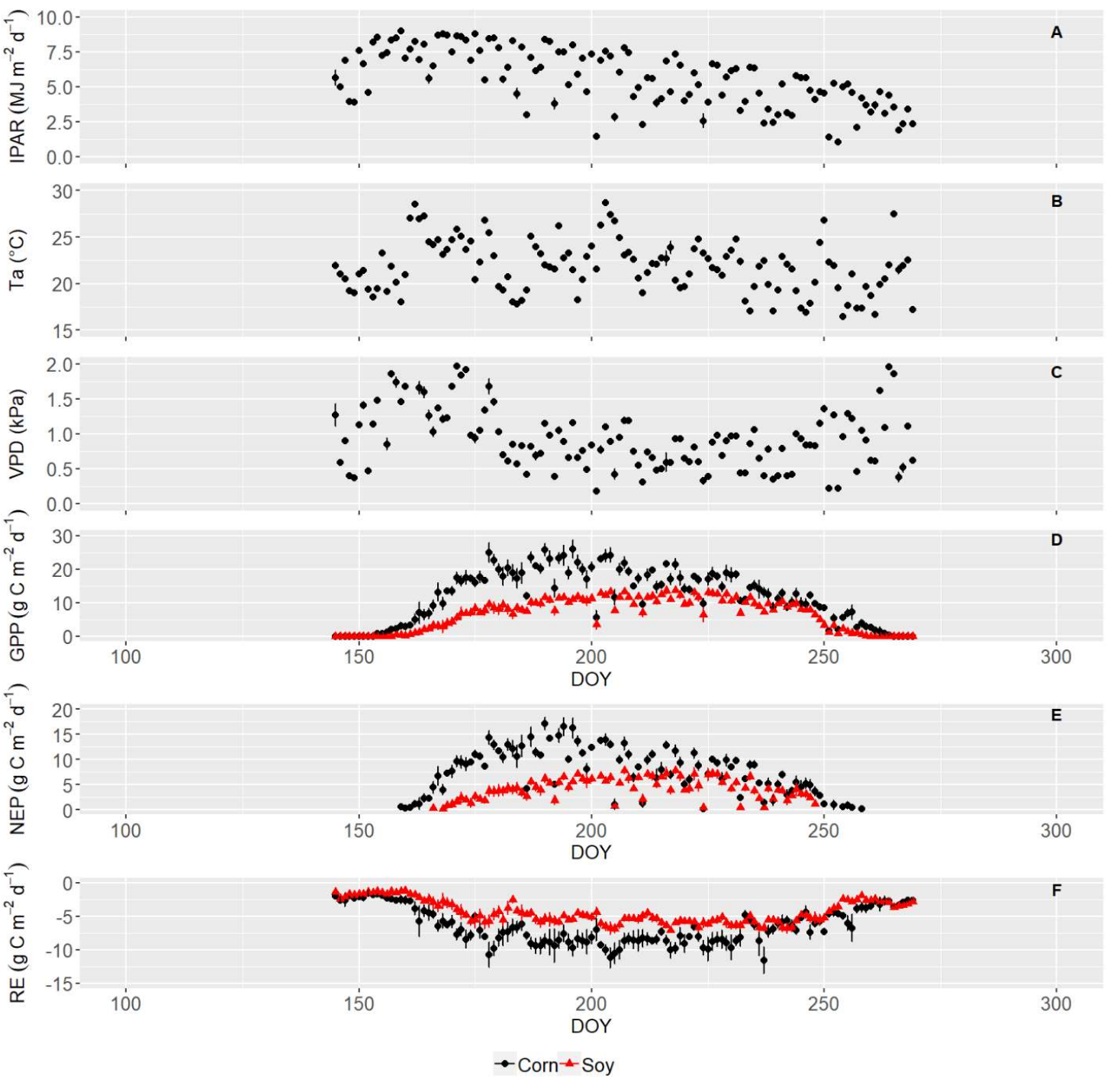

Figure 2. Meteorological data and carbon fluxes for the 2016 growing season in four Iowan counties: (A) Daily incoming photosynthetic active radiation (IPAR, $\mathrm{MJ} \mathrm{m}^{-2} \mathrm{~d}^{-1}$ ), (B) daily ambient air temperature $\left(\mathrm{Ta},{ }^{\circ} \mathrm{C}\right)$, and $(\mathrm{C})$ daytime vapor pressure deficit $(\mathrm{VPD}, \mathrm{kPa})$ averaged $( \pm \mathrm{SE})$ over eight eddy-flux stations. In addition, (D) daily gross primary production (GPP, $\left.\mathrm{g} \mathrm{C} \mathrm{m}^{-2} \mathrm{~d}^{-1}\right)$, (E) daily net ecosystem production (NEP, $\mathrm{g} \mathrm{C} \mathrm{m}^{-2} \mathrm{~d}^{-1}$ ), and (F) ecosystem respiration (RE, $\mathrm{g} \mathrm{C} \mathrm{m}^{-2} \mathrm{~d}^{-1}$ ) averaged over crop $(\mathrm{n}$ $=4)$; red triangles for soybean and black circles for corn.

Table 2. Seasonal (DOY 145-269) NEP, RE, and GPP as well as Yield [1] and calculated Yield GPP, averaged $( \pm$ SE) over four Iowa counties for corn and soybean $(n=4)$ in 2016.

\begin{tabular}{|c|c|c|c|c|c|c|}
\hline Crop & Variable & $\begin{array}{c}\text { NEP } \\
\left(\mathrm{g} \mathrm{C} \mathrm{m}^{-2}\right)\end{array}$ & $\begin{array}{c}\mathrm{RE} \\
\left(\mathrm{g} \mathrm{C} \mathrm{m}^{-2}\right)\end{array}$ & $\begin{array}{c}\text { GPP } \\
\left(\mathrm{g} \mathrm{C} \mathrm{m}^{-2}\right)\end{array}$ & $\begin{array}{l}\text { Yield }_{\mathrm{GPP}} \\
\left(\mathrm{Mg} \mathrm{ha}^{-1}\right)\end{array}$ & $\begin{array}{c}\text { Yield (NASS) } \\
\left(\mathrm{Mg} \mathrm{ha}^{-1}\right)\end{array}$ \\
\hline \multirow[t]{2}{*}{ Corn } & Mean \pm SE & $678 \pm 63$ & $-805 \pm 40$ & $1483 \pm 100$ & $12.82 \pm 0.65$ & $13.09 \pm 0.09$ \\
\hline & $95 \% \mathrm{CI}$ & {$[547,769]$} & {$[-897,-779]$} & {$[1334,1655]$} & - & - \\
\hline \multirow[t]{2}{*}{ Soybean } & Mean \pm SE & $263 \pm 40$ & $-548 \pm 14$ & $811 \pm 53$ & $6.73 \pm 0.27$ & $4.03 \pm 0.04$ \\
\hline & $95 \% \mathrm{CI}$ & {$[170,318]$} & {$[-602,-531]$} & [728,913] & - & - \\
\hline
\end{tabular}

$\mathrm{NEP}=$ net ecosystem production, GPP $=$ gross primary production, $\mathrm{RE}=$ ecosystem respiration, Yield $_{\mathrm{GPP}}=$ yield as calculated with Equation (6). 


\subsection{MODIS FPAR vs NDVI}

The NDVI was measured in one corn and soybean field in Story County and compared to MODIS fPAR products. Field-measured daily corn and soybean NDVI ranged from $0.15-0.88$ and from 0.16-0.91 (Figure 3A). Corn NDVI was $<0.4$ until DOY 156 and after DOY 256, which corresponds to development stages V6 and R6. Soybean NDVI was $<0.4$ until DOY 163 and after DOY 259, which corresponds to phenological stages V3 and V22/R7. Corn reached NDVI values $>0.75$ early in the season at DOY 166, where plants reached phenological stage V8-9 with an average height of $0.95 \mathrm{~m}$.
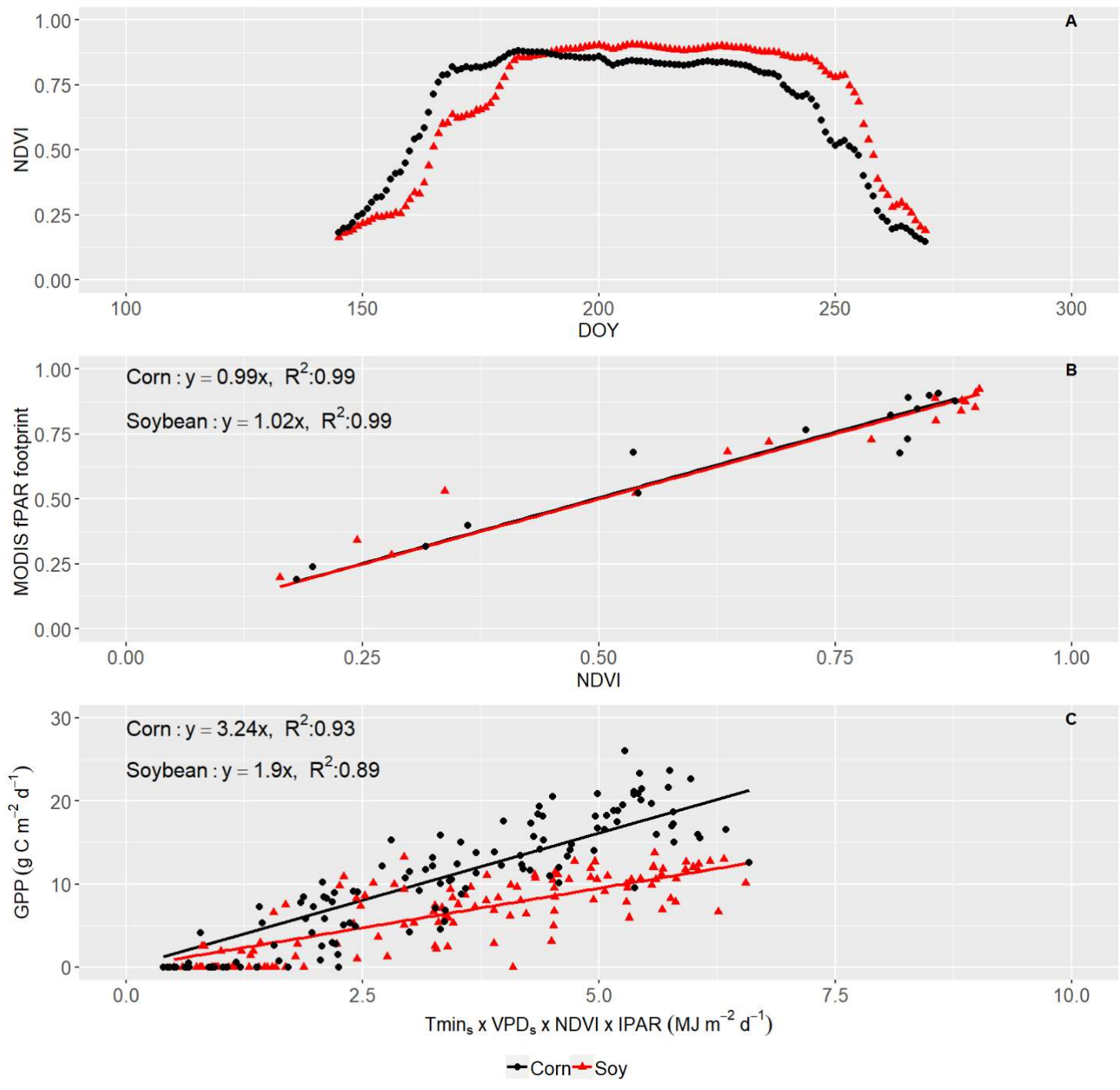

Figure 3. Measurements on the corn (black circles) and soybean (red triangles) field in Story County during the 2016 growing season; (A) measured and interpolated corn and soybean NDVI near the eddy-flux stations; (B) linear regression analysis $(\mathrm{p}<0.05)$ with measured NDVI as independent and MODIS fPAR in the $90 \%$ footprint area as dependent variable; $(\mathrm{C})$ linear regression analysis $(\mathrm{p}<0.05)$ with the product of the Tmin $, V_{\mathrm{sPD}}, \mathrm{NDVI}$, and IPAR $\left(\mathrm{MJ} \mathrm{m} \mathrm{m}^{-2} \mathrm{~d}^{-1}\right)$ as independent and GPP $(\mathrm{g} \mathrm{C}$ $\mathrm{m}^{-2} \mathrm{~d}^{-1}$ ) as dependent variable with the slope being RUEmax. $\mathrm{R}^{2}$ : coefficient of determination, Tmin : $_{\mathrm{s}}$ : temperature scalar, $\mathrm{VPD}_{\mathrm{s}}$ : vapor pressure deficit scalar, IPAR: incoming photosynthetic active radiation, GPP: gross primary production, RUE $_{\max }$ : maximum radiation use efficiency. 
Soybean NDVI reached values $>0.75$ later than corn at DOY 180, corresponding to plant development stage V8-10/R1-2 and an average height of approximately $0.40 \mathrm{~m}$. There was a significant linear relationship $(\mathrm{p}<0.05)$ between field-measured NDVI and MODIS fPAR within the $90 \%$ footprint area of the EC station, explaining $99 \%$ of the fPAR variation with a slope of 1.02 and 0.99 for corn and soybean, respectively (Figure 3B).

The RUE $E_{\max }$ was then calculated with Equation (3), substituting fPAR with NDVI and using meteorological data and GPP from the EC stations in the studied corn and soybean field in Story County. The RUE $E_{\max }$ was the slope of a linear regression with GPP as dependent and the product of Tmin, VPDmin, IPAR, and NDVI as independent variables. The derived daily corn and soybean $\mathrm{RUE}_{\max }$ was 3.24 and $1.90 \mathrm{~g} \mathrm{C} \mathrm{MJ}^{-1}$. The linear relationship was significant at $\mathrm{p}<0.05$, explaining $93 \%$ and $89 \%$ of the GPP variation for corn and soybean, respectively (Figure 3C).

\subsection{Upscaling GPP to County Level}

The total corn and soybean area from the ACPF land use maps corresponded well with the official production area in 2016 [1] $\left(y=1.01 x ; R^{2}=0.99, p<0.05, n=8\right)$. The land use maps also corresponded well with the MODIS land cover in 2016, and $>99 \%$ of the ACPF map area used was classified as cropland in the MODIS land cover map. The average ( \pm SE) ACPF land use area of corn and soybean in 2016 made up $55 \% \pm 2 \%$ and $26 \% \pm 1 \%$ of the total land area in four counties, respectively.

The average within-county fPAR range (difference between maximum and minimum fPAR) was 0.65 at DOY 145, decreased to 0.32 at DOY 201 and increased again to 0.65 at DOY 265 (Figure 4, Video S1). The county median fPAR ranged from $0.25-0.9$ with little variation among crops and counties during the 2016 growing season (Figure 5A). Calculated daily corn and soybean GPP followed a seasonal pattern with highest values at 22.1 and $11.7 \mathrm{~g} \mathrm{C} \mathrm{m}^{-2} \mathrm{~d}^{-1}$, respectively (Figure 5B). A linear regression between EC-derived GPP and GPP calc within the $90 \%$ footprint was significant at $\mathrm{p}<0.05$, with a coefficient of determination $\left(\mathrm{R}^{2}\right)$ of 0.96 and 0.86 and a root mean square error (RMSE) of 2.24 and $2.81 \mathrm{~g} \mathrm{C} \mathrm{m}^{-2} \mathrm{~d}^{-1}$, for corn and soybean, respectively (Figure 5C). A linear regression between EC-derived GPP and daily GPP MODIS within the $90 \%$ footprint was significant at $\mathrm{p}<0.05$, with a $\mathrm{R}^{2}$ of 0.89 and 0.21 and a RMSE of 2.44 and $3.30 \mathrm{~g} \mathrm{C} \mathrm{m}^{-2} \mathrm{~d}^{-1}$ for corn and soybean, respectively. GPP $\mathrm{MODIS}_{\mathrm{S}}$ was not substantially different between crops, overestimated GPP at the onset and end of the season, and underestimated corn GPP (Figures A2 and A3).

The average within-county corn and soybean $\mathrm{GPP}_{\text {calc }}$ range (difference between maximum and minimum GPP calc $_{\text {) }}$ was 13.2 and $6.0 \mathrm{~g} \mathrm{C} \mathrm{m}^{-2} \mathrm{~d}^{-1}$ at DOY 145 , decreased to 1.5 and $0.9 \mathrm{~g} \mathrm{C} \mathrm{m}^{-2} \mathrm{~d}^{-1}$ at DOY 201 and increased again to 5.1 and $3.6 \mathrm{~g} \mathrm{C} \mathrm{m}^{-2} \mathrm{~d}^{-1}$ at DOY 265 (Figure 6). The Yield $\mathrm{GPP}_{\text {was }} 12.82$ \pm 0.65 and $6.73 \pm 0.27 \mathrm{Mg} \mathrm{ha}^{-1}$, for corn and soybean, respectively (Table 2). The official county-wide corn and soybean yield in 2016 was $13.09 \pm 0.09$ and $4.03 \pm 0.04 \mathrm{Mg} \mathrm{ha}^{-1}$, respectively [1]. 


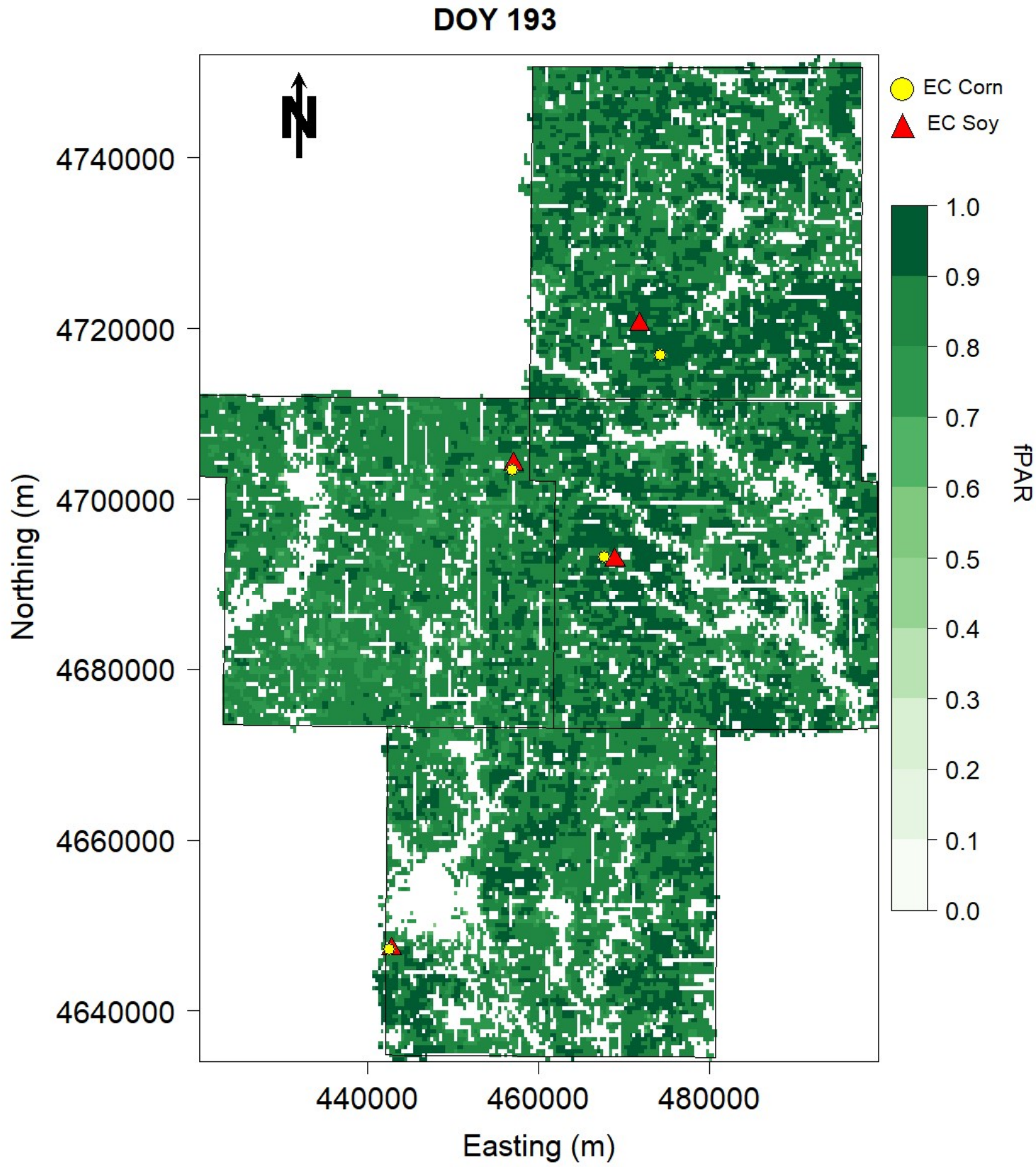

Figure 4. MODIS fPAR product (MCD15A2H) for DOY 193 in 2016 in four Iowan counties for corn and soybean fields. The red triangles and yellow circles show the location of the eddy covariance (EC) stations on soybean and corn fields, respectively; fPAR: fraction of absorbed photosynthetic active radiation. 

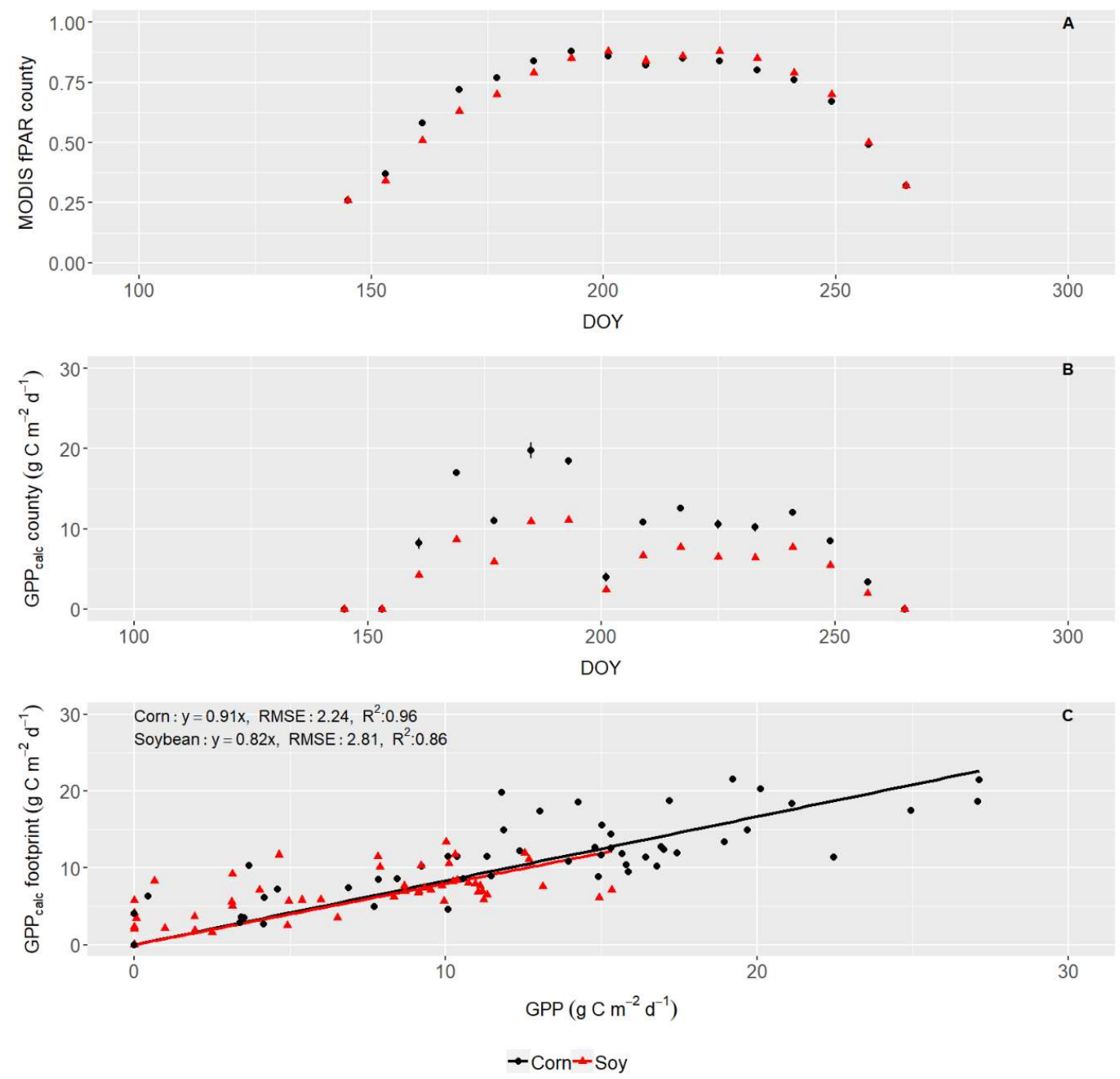

Figure 5. $\mathrm{GPP}_{\text {calc }}$ as calculated with MODIS fPAR product for corn (black circles) and soybean (red triangles) for 2016: (A) median county fPAR, averaged $( \pm \mathrm{SE})$ over county $(n=4),(B)$ daily median county $\mathrm{GPP}_{\text {calc }}\left(\mathrm{g} \mathrm{C} \mathrm{M}^{-2} \mathrm{~d}^{-1}\right)$ averaged over county, and $(\mathrm{C})$ linear regression analysis $(\mathrm{p}<0.05)$ with daily EC-derived GPP as independent and $90 \%$ footprint $\mathrm{GPP}_{\text {calc }}\left(\mathrm{g} \mathrm{C} \mathrm{m}^{-2} \mathrm{~d}^{-1}\right)$ as dependent variable, $\mathrm{R}^{2}$ : coefficient of determination, GPP: gross primary production, fPAR: fraction of absorbed photosynthetic active radiation. 


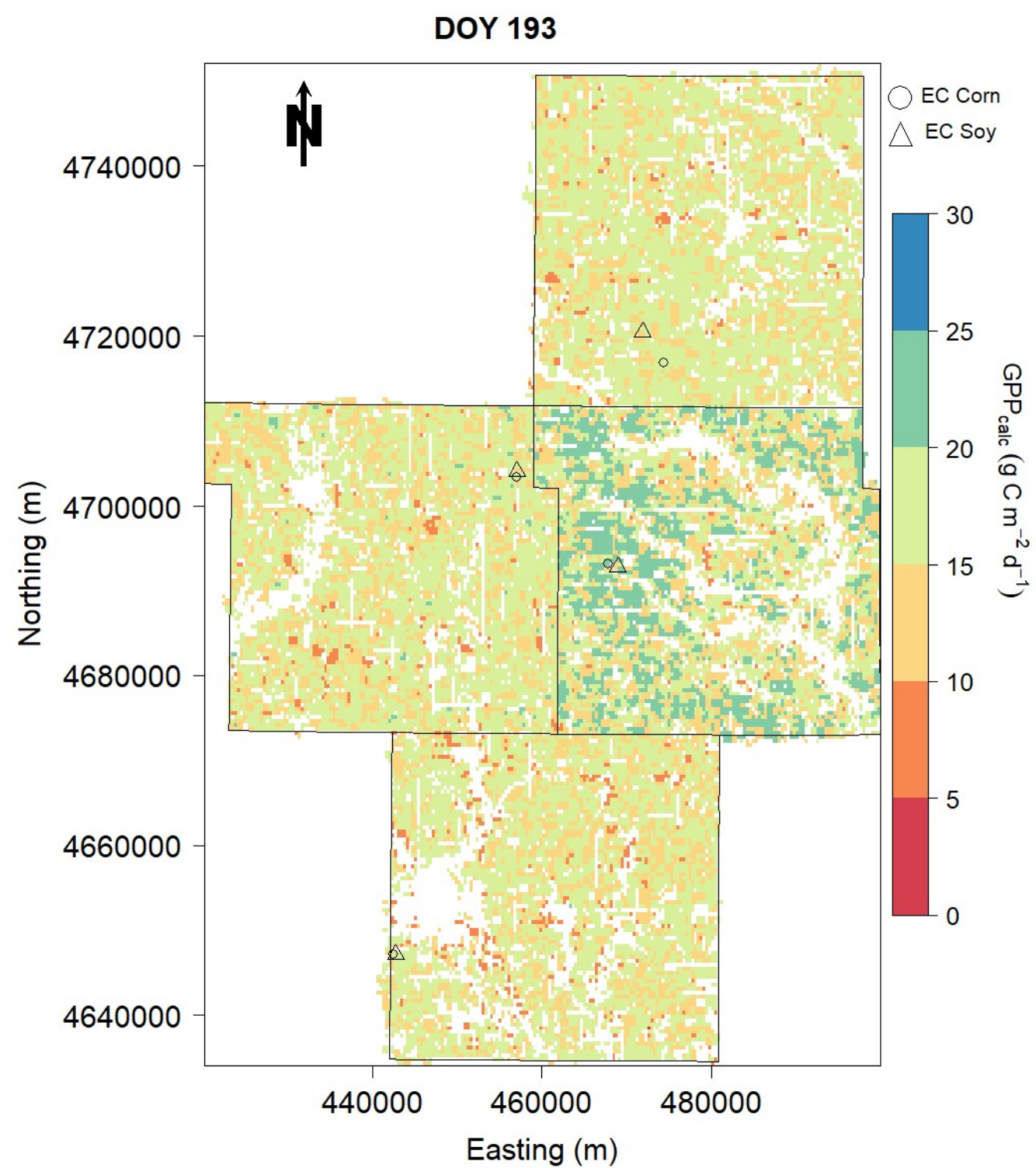

Figure 6. Daily GPP $\mathrm{calc}_{\mathrm{c}}\left(\mathrm{g} \mathrm{C} \mathrm{m}^{-2} \mathrm{~d}^{-1}\right)$ on DOY 193 in 2016 for four Iowa counties. Triangles and circles show the location of the eddy covariance (EC) stations in soybean and corn fields, respectively.

\section{Discussion}

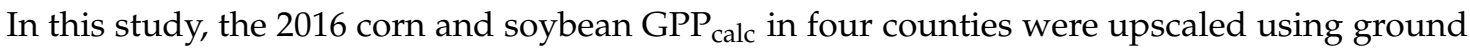
measurements of GPP, NDVI, and meteorological data as well as MODIS fPAR products. In contrast to previous studies, seasonal GPP, NEP, and RE from several EC stations concentrated on a relatively small land area were retrieved. It was therefore possible to estimate the spatial variation of GPP under similar climate conditions and for a relatively small land area as compared to previous studies [12-15]. The calculated 95\% CI indicate a substantial variation in GPP, NEP, and RE among sites, despite that the studied fields are well represented in the four counties [5] and the relatively high density of EC stations used. Individual spatial variation in GPP is probably connected to climate, soil and crop management (Table 1, Table 2), such as precipitation, cloud cover, crop growth, crop varieties, fertilizer application, tillage, and amount of crop residues among others. Analyzing for these impacting factors was beyond the scope of this study and would require more information of each field but may be important to further increase the accuracy of $\mathrm{GPP}_{\text {calc. }}$. In a previous study, substantial variation in corn and soybean $\mathrm{F}_{\mathrm{C}}$ and precipitation using 12 EC stations in a 5000-ha Midwestern US watershed was found, and this was accounted to difference in ground cover, plant growth and biomass accumulation 
among fields [47]. Differences in soil tillage has also impacted GPP [4], and soil respiration varies with nitrogen fertilizer application, irrigation, and tillage [48]. This indicates that a higher density of EC stations than typically used in field studies is needed to cover the spatial variation of GPP calc. The higher NEP values in corn are connected to higher photosynthetic rates of corn as a 44 crop, compared to soybean as a $\mathrm{C} 3 \mathrm{crop}$. In addition, high amounts of corn residues from the previous season remain in the soybean fields, which further decreases NEP due to higher residue mineralization [27].

The GPP calc $_{\text {c was more accurate than GPP }}$ MODIS, as evidenced by lower RMSE in comparison to EC-derived GPP. Field measurements of RUE $E_{\max }$, improved land use maps, and a higher resolution of IPAR, Ta, and VPD measurements increased the accuracy of $\mathrm{GPP}_{\text {calc }}$ compared to GPP $\mathrm{MODIS}_{\text {. }}$

One important tool to increase the accuracy of GPP ${ }_{\text {calc }}$ compared to GPP $\mathrm{MODIS}_{\text {was }}$ we ACPF land use map [18], which enabled distinction between corn and soybean fields within each county. The ACPF land use maps are based on an ensemble of aerial photographs, satellite imagery, and other land use map products [18]. Earlier studies on corn and soybean production in the Midwestern US were constraint to the Cropland Data Layer (CDL) and an area-weighted, crop-specific value was used to estimate GPP contribution by crop [12,13]. To the best of our knowledge, this is the first time that

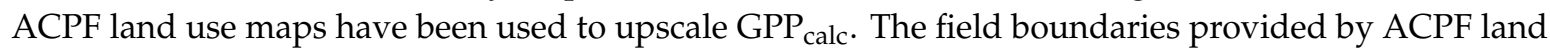
use maps were the basis to create $\mathrm{GPP}_{\text {calc }}$ maps as separated by crop. Approximately, $\frac{3}{4}$ of the total land area in the studied counties were used for corn and soybean production, which demonstrates the economic importance and its impact on the carbon cycle in the region. There were more fields used for corn than for soybean production in the studied counties in 2016, and corn GPP (as a C4 crop) was higher than soybean GPP (as a C3 crop) (Figure 2D). Consequently, the tempo-spatial variation in corn and soybean fields determines the amount of county-wide, seasonal cropland GPP $\mathrm{Falc}_{\text {ca }}$. Accurate and annually updated land use maps are therefore imperative to upscale $\mathrm{GPP}_{\text {calc }}$ and is important to improve GPP MODIs.

Another significant parameter to improve GPP the maximum amount of GPP per unit of absorbed IPAR (i.e., fPAR $\times$ IPAR). Similar corn and soybean $\mathrm{RUE}_{\max }$ of 3.17 and $1.91 \mathrm{~g} \mathrm{C} \mathrm{MJ}^{-1}$ had previously been reported using EC data and MODIS fPAR in corn and soybean fields in the Midwestern US [12]. For the GPP MODIs product the RUEmax is determined according to land cover categories (from MODIS MCD12Q1 land cover types), and a cropland RUE $\max$ of $1.044 \mathrm{~g} \mathrm{C} \mathrm{MJ}^{-1}$ was proposed [6]. This is lower than the corn and soybean $\mathrm{RUE}_{\max }$ in this study and does not distinguish between both crops. This consequently leads to the substantial underestimation

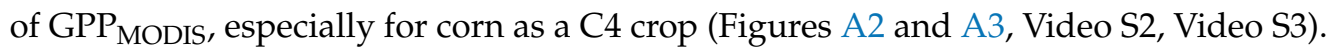

The MODIS fPAR product within the EC footprint corresponded well with NDVI measurements on the ground for both crops, which is interesting considering the difference in resolution (i.e., $500 \times 500 \mathrm{~m}$ satellite image vs. $1.5 \mathrm{~m} \times 1.5 \mathrm{~m}$ pixel size of field measurement). It also indicates that MODIS fPAR displays the NDVI of both crops. It was also noted that Equation (3) overestimates GPP calc at the beginning and the end of the growing season, where the EC-measured GPP was zero (Figure A2). This problem was somewhat resolved by setting $\mathrm{GPP}_{\text {calc }}$ to zero, when fPAR $<0.4$ (i.e., early and late in plant development). A field-measured NDVI value of 0.15 was found for bare soil in corn and soybean, similar to this study [28], and GPP is zero. It is likely that NDVI and MODIS fPAR do not represent $\mathrm{GPP}_{\text {calc }}$ well in the early and late stages of plant development, despite that NDVI was found to be a good indicator of intercepted PAR [35]. A field-based fPAR as well as other MODIS imagery-derived VIs further improved GPP calc in corn and soybeans [14,15].

The importance of RUE $E_{\max }$, fPAR, and land use maps should not diminish the importance of accurate meteorological data, as it determines the amount of energy intercepted by the crop (IPAR) and to what extent RUE is limited by temperature and VPD constraints (i.e., $\mathrm{Tmin}_{\mathrm{s}}$ and $\mathrm{VPD}_{\mathrm{s}}$ scalars). This

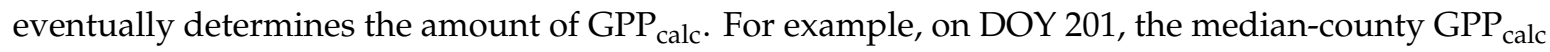
was low, because IPAR was low at all eight EC stations (Figures 2A and 5B). Although the variation of IPAR, Ta, and VPD was low among EC stations (Figure 2), these variables impacted among-county daily GPP calc $_{\text {variation. For example, corn GPP }}$ calc on DOY 193 was higher in Hardin county owing to 
slightly higher $\mathrm{VPD}_{\mathrm{s}}$ and IPAR (Figure 6, Video S3). Political boundary delimitations (i.e., counties) are not connected to these climatic changes, and further methods are needed to model the spatial variation of IPAR, Ta, and VPD with higher resolution. Within-county variation of corn and soybean $\mathrm{GPP}_{\text {calc }}$ is therefore only driven by the MODIS fPAR products in this study. In this study, IPAR, Ta, and VPD from ground measurements were used because of the relatively high resolution among stations. However, this may not always be the case. For example, the global GPP MODIS product is calculated with meteorological data provided from the NCEP-DOE reanalysis II datasets, which have a coarser resolution than the density of EC stations used in this study [49].

The seasonal sum of county-median $\mathrm{GPP}_{\text {calc }}$ was used to estimate Yield $_{\mathrm{GPP}}$, which was compared

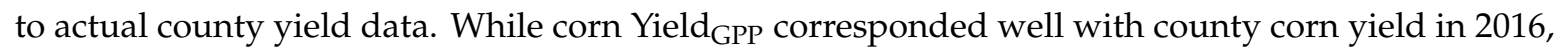
soybean Yield $\mathrm{GPP}_{\mathrm{GP}}$ was overestimated (Table 2). There has been good agreement between Yield $\mathrm{GPP}_{\mathrm{G}}$ and actual yield values in corn and soybean [13], and wheat [7], however, both studies found limitations

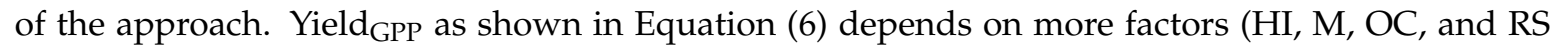
may differ among fields) than $\mathrm{GPP}_{\text {calc }}$ and this estimation only represents a general trend. The overestimation of soybean Yield ${ }_{\mathrm{GPP}}$ could be connected to the mineralization of the 2015 corn residues in soybean-years in these corn-soybean rotation systems. The mineralization of corn residues from the previous growing season can have a substantial impact on current-year soybean NEP, GPP, and $\mathrm{RE}$ [4]; thus, the $\mathrm{GPP}_{\text {calc }}$ as combined value of corn residue respiration and soybean assimilation may underrepresent soybean yield.

\section{Conclusions}

It was shown in this study, that $\mathrm{GPP}_{\text {calc }}$ can be upscaled with higher accuracy (i.e., lower RMSE) than GPP MODIS. The GPP MODIS product does not distinguish among crops, which leads to a substantial underestimation of $\mathrm{C} 4$ crops such as corn. The fPAR MODIS product agreed with ground-measured NDVI. The meteorological data showed low variation among EC stations, indicating that a coarse-resolution meteorological dataset may be sufficient to upscale regional bulk GPP in this region of Iowa. However, variation of soil and crop management as well as micro-climate may require a higher density of $\mathrm{EC}$ and weather stations to estimate $\mathrm{GPP}_{\text {calc }}$ on a field level. A substantial improvement of upscaling regional GPP can be achieved using crop-specific RUE $_{\max }$ and improved land use maps. A more detailed categorization of MODIS land use maps (e.g., cropland C4 crops vs. cropland C3 crops), a crop-specific RUEmax, and a different VI for the beginning and end of the

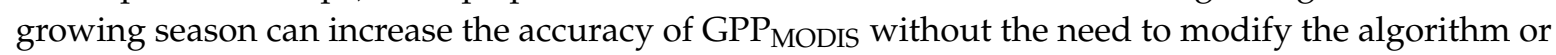
substantial re-processing of imagery.

Supplementary Materials: The following are available online at http://www.mdpi.com/2072-4292/11/14/1688/s1, Video S1: MODIS fPAR, Video S2: GPPMODIS, Video S3: GPP calc.

Author Contributions: For research articles with several authors, a short paragraph specifying their individual contributions must be provided. The following statements should be used "conceptualization, C.D., K.M.W. and J.H.P.; methodology, C.D., K.M.W., and J.H.P.; software, C.D. and J.H.P.; validation, C.D.; formal analysis, C.D. and J.H.P.; investigation, C.D. and J.H.P.; resources, J.L.H., J.H.P., T.B.M., T.J.S., M.H.C. and D.D.; data curation, C.D.; writing-original draft preparation, C.D.; writing—review and editing, C.D., K.M.W., J.L.H., J.H.P., T.B.M., T.J.S., M.H.C. and D.D.; visualization, C.D.; supervision, J.L.H. and J.H.P.; project administration, J.L.H., J.H.P., T.B.M., T.J.S., M.H.C. and D.D.; funding acquisition, JH, TM and TS", please turn to the CRediT taxonomy for the term explanation. Authorship must be limited to those who have contributed substantially to the work reported.

Funding: This research was supported in part by an appointment to the Agricultural Research Service (ARS) Research Participation Program administered by the Oak Ridge Institute for Science and Education (ORISE) through an interagency agreement between the U.S. Department of Energy (DOE) and the U.S. Department of Agriculture (USDA). ORISE is managed by ORAU under DOE contract number DE-AC05-06OR23100. USDA is an equal opportunity provider and employer. All opinions expressed in this paper are the author's and do not necessarily reflect the policies and views of USDA, ARS, DOE, or ORAU/ORISE.

Acknowledgments: This study would not be possible without the capable support of Wolf Oesterreich to collect and process the NDVI data, Sarah Porter to work on the land use maps, and Forrest Goodman to maintain the eddy-flux stations. 
Conflicts of Interest: The authors declare no conflict of interest.

\section{Abbreviations}

\begin{tabular}{|c|c|}
\hline $\mathrm{ACPF}$ & Agricultural Conservation Planning Framework \\
\hline AQY & apparent quantum yield \\
\hline $\mathrm{CI}$ & confidence intervals \\
\hline DOY & day of the year \\
\hline $\mathrm{e}_{\mathrm{a}}$ & actual vapor pressure \\
\hline $\mathrm{e}_{\mathrm{s}}$ & saturated vapor pressure \\
\hline $\mathrm{EC}$ & eddy covariance \\
\hline fPAR & fraction of absorbed photosynthetic active radiation \\
\hline $\mathrm{F}_{\mathrm{C}}$ & carbon dioxide flux \\
\hline GPP & gross primary production \\
\hline IPAR & incoming photosynthetic active radiation \\
\hline HI & Harvest index \\
\hline IQR & interquartile range \\
\hline M & $\%$ moisture content \\
\hline MODIS & Moderate resolution Imaging Spectroradiometer \\
\hline NDVI & Normalized Difference Vegetation Index \\
\hline NEP & net ecosystem production \\
\hline OC & $\%$ grain carbon content \\
\hline$P_{g \text { max }}$ & maximum gross photosynthesis rate \\
\hline $\mathrm{Rd}$ & daytime respiration \\
\hline RE & ecosystem respiration \\
\hline $\mathrm{rH}$ & relative humidity \\
\hline RS & root-shoot ratio \\
\hline RUE $_{\max }$ & maximum radiation use efficiency \\
\hline $\mathrm{Ta}$ & air temperature \\
\hline $\mathrm{Tlim}_{\min / \max }$ & lower and upper boundary of daily minimum air temperature \\
\hline $\operatorname{Tmin}_{\mathrm{s}}$ & temperature scalar \\
\hline VPD & daytime vapor pressure deficit \\
\hline $\mathrm{VPD}_{\min / \max }$ & $\begin{array}{l}\text { lower and upper boundary of daily daytime vapor pressure } \\
\text { deficit }\end{array}$ \\
\hline $\mathrm{VPD}_{\mathrm{s}}$ & vapor pressure deficit scalar \\
\hline Yield $\mathrm{GPP}$ & grain yield calculated from GPP \\
\hline
\end{tabular}




\section{Appendix A. Flux Footprints}
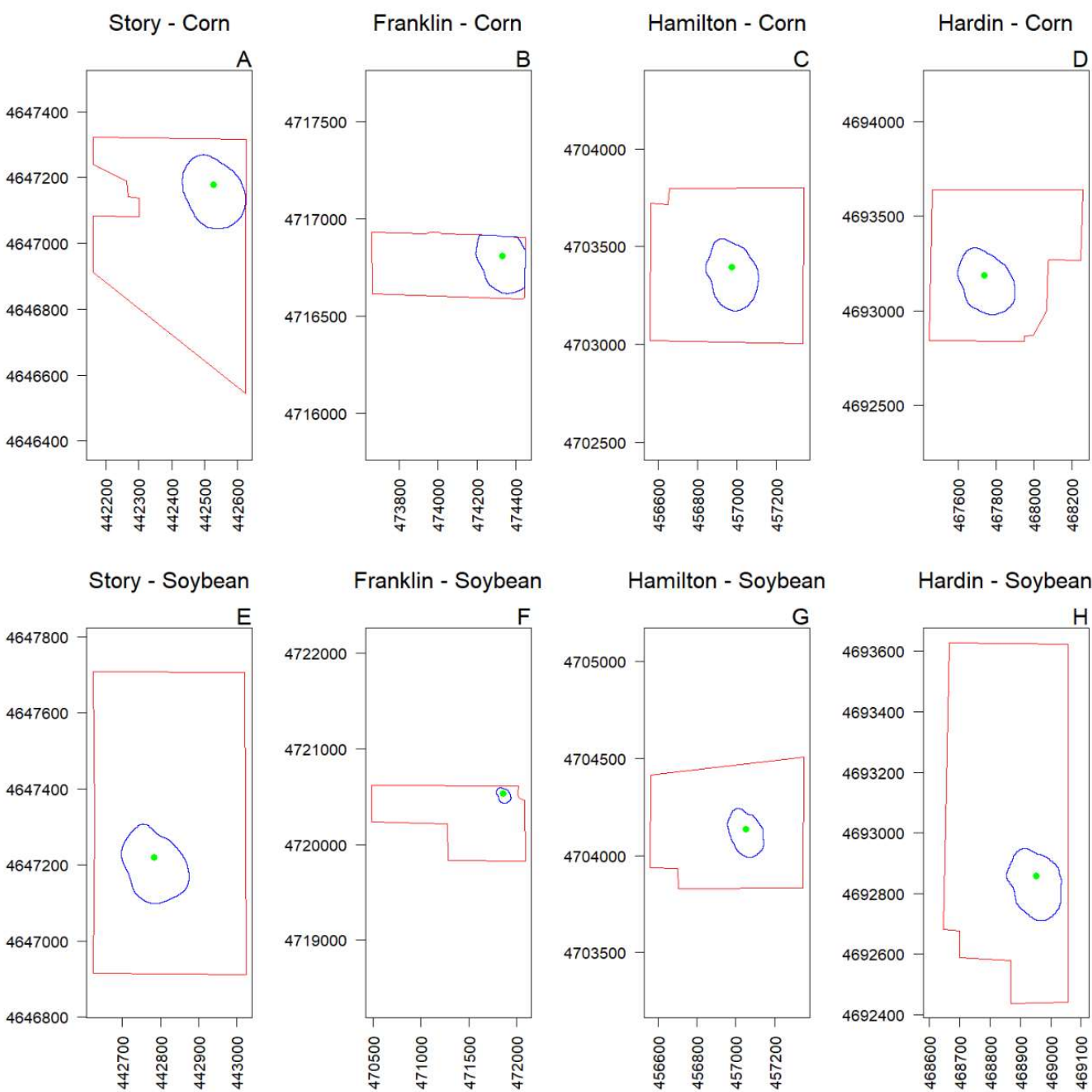

Hardin - Soybean

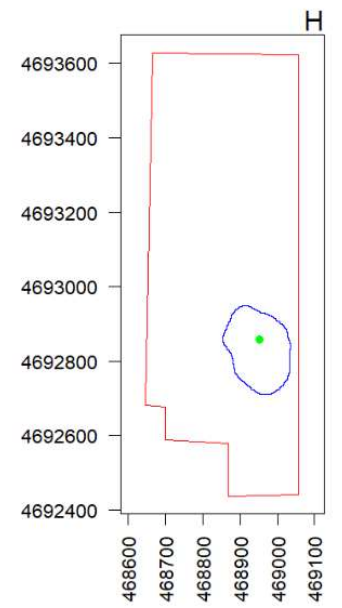

Figure A1. The average 90\% flux footprint area (blue borders) of each EC station (green circles) within corn (A-D) and soybean (E-H) fields (red borders) in Story, Franklin, Hamilton, and Hardin County, Iowa. 


\section{Appendix B. MODIS GPP Product vs. Field-Measured GPP}

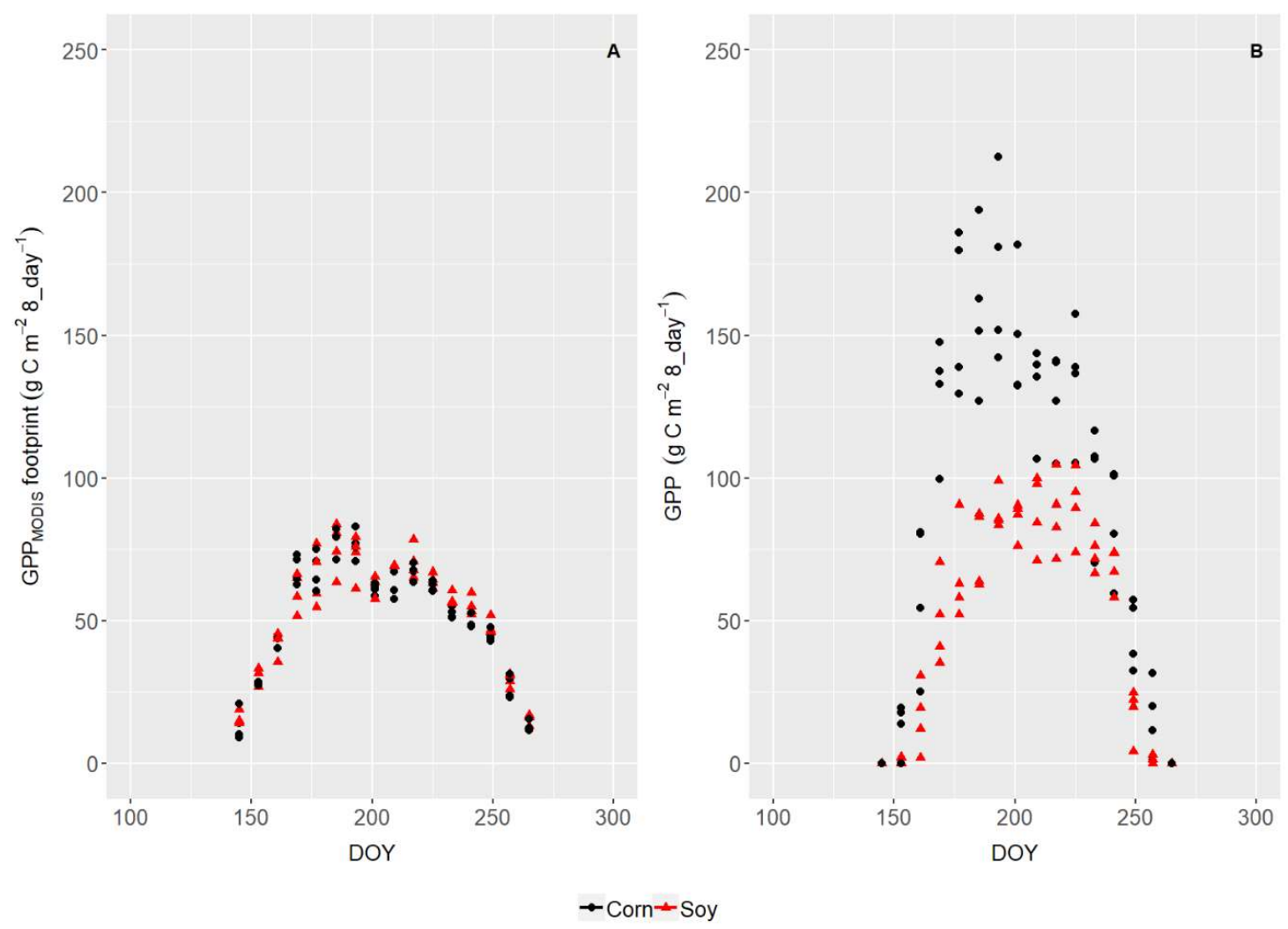

Figure A2. The gross primary production (GPP) averaged for corn (black circles, $n=4$ ) and soybean (red triangles, $n=4$ ) in four counties in North Central Iowa during the 2016 growing season (DOY 145-269); (A) The 8-day GPP MODIS product $\left(\mathrm{g} \mathrm{C} \mathrm{m}^{-2} 8\right.$-day $\left.{ }^{-1}\right)$ within the $90 \%$ footprint area of the EC station. (B) The 8-day-sum of EC-derived GPP $\left(\mathrm{g} \mathrm{C} \mathrm{m}^{-2} 8\right.$-day $\left.{ }^{-1}\right)$. 


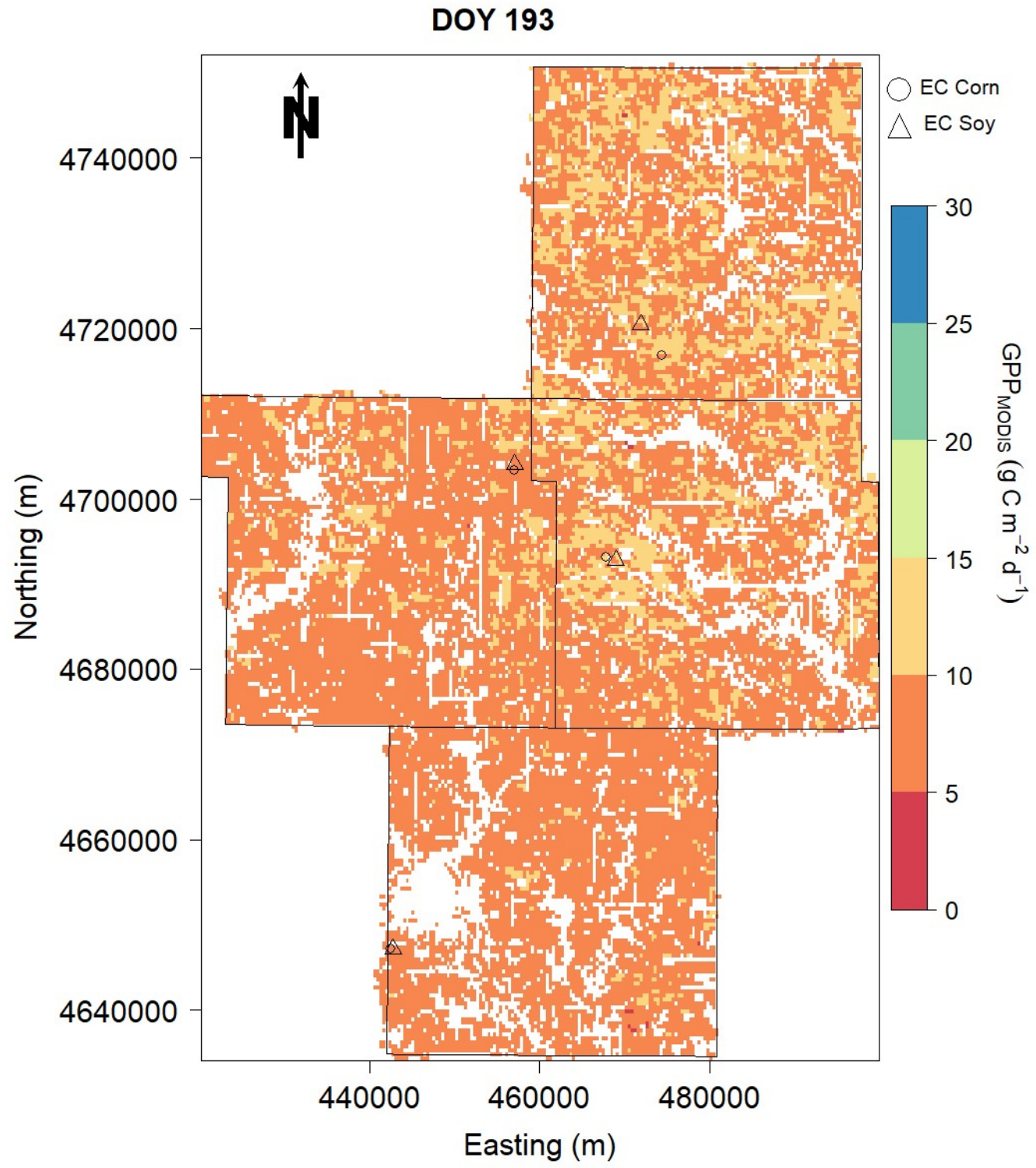

Figure A3. Daily GPP MODIS product $\left(\mathrm{g} \mathrm{C} \mathrm{m}^{-2} \mathrm{~d}^{-1}\right)$ on DOY 193 in 2016 for four Iowa counties. Triangles and circles show the location of the eddy covariance (EC) stations in soybean and corn fields, respectively.

\section{References}

1. National Agricultural Statistics Service (NASS). Available online: https://www.nass.usda.gov/Publications/ Ag_Statistics/index.php (accessed on 4 April 2019).

2. FAOSTAT. Food and Agriculture Organization of the United Nations, Statistics Division. Forestry Production and Trade. Available online: http://www.fao.org/faostat/en/\#data/FO (accessed on 4 April 2019).

3. Guanter, L.; Zhang, Y.; Jung, M.; Joiner, J.; Voigt, M.; Berry, J.A.; Frankenberg, C.; Huete, A.R.; Zarco-Tejada, P.J.; Lee, J.E.; et al. Global and time-resolved monitoring of crop photosynthesis with chlorophyll fluorescence. Proc. Natl. Acad. Sci. USA 2014, 111, E1327-E1333. [CrossRef] [PubMed]

4. Dold, C.; Hatfield, J.L.; Prueger, J.H.; Sauer, T.J.; Moorman, T.B.; Wacha, K.M. Impact of Management Practices on Carbon and Water Fluxes in Corn-Soybean Rotations. AGE 2019, 2, 1-8. [CrossRef]

5. USDA-NASS. 2017 Census of Agriculture. Available online: https:/www.nass.usda.gov/Publications/ AgCensus/2017/Full_Report/Volume_1,_Chapter_1_State_Level/Iowa/ (accessed on 9 July 2019). 
6. Running, S.W.; Zhao, M. Daily GPP and Annual NPP (MOD17A2/A3) Products NASA Earth Observing System MODIS Land Algorithm. Version 3.0; 2015; p. 28. Available online: https:/landweb.modaps.eosdis. nasa.gov/QA_WWW/forPage/user_guide/MOD17UsersGuide2015v3.pdf (accessed on 19 March 2019).

7. Reeves, M.C.; Zhao, M.; Running, S.W. Usefulness and limits of MODIS GPP for estimating wheat yield. Int. J. Remote Sens. 2005, 26, 1403-1421. [CrossRef]

8. Ryu, Y.; Baldocchi, D.D.; Kobayashi, H.; Van Ingen, C.; Li, J.; Black, T.A.; Beringer, J.; Van Gorsel, E.; Knohl, A.; Law, B.E.; et al. Integration of MODIS land and atmosphere products with a coupled-process model to estimate gross primary productivity and evapotranspiration from $1 \mathrm{~km}$ to global scales. Glob. Biogeochem. Cycles 2011, 25, 25. [CrossRef]

9. Jiang, C.; Ryu, Y. Multi-scale evaluation of global gross primary productivity and evapotranspiration products derived from Breathing Earth System Simulator (BESS). Remote Sens. Environ. 2016, 186, 528-547. [CrossRef]

10. Coops, N.; Black, T.; Jassal, R.; Trofymow, J.; Morgenstern, K. Comparison of MODIS, eddy covariance determined and physiologically modelled gross primary production (GPP) in a Douglas-fir forest stand. Remote Sens. Environ. 2007, 107, 385-401. [CrossRef]

11. Wu, C.; Munger, J.W.; Niu, Z.; Kuang, D. Comparison of multiple models for estimating gross primary production using MODIS and eddy covariance data in Harvard Forest. Remote Sens. Environ. 2010, 114, 2925-2939. [CrossRef]

12. Xin, Q.; Broich, M.; Suyker, A.E.; Yu, L.; Gong, P. Multi-scale evaluation of light use efficiency in MODIS gross primary productivity for croplands in the Midwestern United States. Agric. For. Meteorol. 2015, 201, 111-119. [CrossRef]

13. Xin, Q.; Gong, P.; Yu, C.; Yu, L.; Broich, M.; Suyker, A.E.; Myneni, R.B. A Production Efficiency Model-Based Method for Satellite Estimates of Corn and Soybean Yields in the Midwestern US. Remote Sens. 2013, 5 , 5926-5943. [CrossRef]

14. Zhang, Q.; Cheng, Y.-B.; Lyapustin, A.I.; Wang, Y.; Gao, F.; Suyker, A.; Verma, S.; Middleton, E.M. Estimation of crop gross primary production (GPP): fAPARchl versus MOD15A2 FPAR. Remote Sens. Environ. 2014, 153, 1-6. [CrossRef]

15. Zhang, Q.; Cheng, Y.B.; Lyapustin, A.I.; Wang, Y.; Zhang, X.; Suyker, A.; Verma, S.; Shuai, Y.; Middleton, E.M. Estimation of crop gross primary production (GPP): II. Do scaled MODIS vegetation indices improve performance? Agric. For. Meteorol. 2015, 200, 1-8. [CrossRef]

16. Sjöström, M.; Zhao, M.; Archibald, S.; Arneth, A.; Cappelaere, B.; Falk, U.; De Grandcourt, A.; Hanan, N.; Kergoat, L.; Kutsch, W.; et al. Evaluation of MODIS gross primary productivity for Africa using eddy covariance data. Remote Sens. Environ. 2013, 131, 275-286. [CrossRef]

17. Turner, D.P.; Ritts, W.D.; Cohen, W.B.; Gower, S.T.; Running, S.W.; Zhao, M.; Costa, M.H.; Kirschbaum, A.A.; Ham, J.M.; Saleska, S.R.; et al. Evaluation of MODIS NPP and GPP products across multiple biomes. Remote Sens. Environ. 2006, 102, 282-292. [CrossRef]

18. Tomer, M.D.E.; James, D.; Sandoval-Green, C.M.J. Agricultural Conservation Planning Framework: 3. Land Use and Field Boundary Database Development and Structure. J. Environ. Qual. 2017, 46, 676-686. [CrossRef] [PubMed]

19. Cosh, M.H.; White, W.A.; Colliander, A.; Jackson, T.J.; Prueger, J.H.; Hornbuckle, B.K.; Hunt, E.R.; McNairn, H.; Powers, J.; Walker, V.A.; et al. Estimating vegetation water content during the Soil Moisture Active Passive Validation Experiment 2016. J. Appl. Remote Sens. 2019, 13, 014516. [CrossRef]

20. Colliander, A.; Cosh, M.H.; Misra, S.; Jackson, T.J.; Crow, W.T.; Powers, J.; McNairn, H.; Bullock, P.; Berg, A.; Magagi, R.; et al. Comparison of high-resolution airborne soil moisture retrievals to SMAP soil moisture during the SMAP validation experiment 2016 (SMAPVEX16). Remote Sens. Environ. 2019, 227, 137-150. [CrossRef]

21. USDA-NRCS. Soil Survey Geographic (SSURGO) Database for Hardin, Franklin, Hamilton E Story County, Iowa; Soil Survey Staff, Natural Resources Conservation Service, United States Department of Agriculture: Washington, DC, USA, 2018.

22. IEM. Iowa Environmental Mesonet-Climate Data. Available online: https://mesonet.agron.iastate.edu/ (accessed on 10 October 2018).

23. Burba, G. Eddy Covariance Method for Scientific, Industrial, Agricultural and Regulatory Applications: A Field Book on Measuring Ecosystem Gas. Exchange and Areal Emission Rates; LI-COR Biosciences: Lincoln, NE, USA, 2013; p. 331. 
24. Kljun, N.; Calanca, P.; Rotach, M.W.; Schmid, H.P. A simple two-dimensional parameterisation for Flux Footprint Prediction (FFP). Geosci. Model. Dev. 2015, 8, 3695-3713. [CrossRef]

25. Tanner, C.B.; Thurtell, G.W. Anemoclinometer Measurements of Reynolds Stress and Heat Transport in the Atmospheric Surface Layer; Department of Soil Science Wisconsin University: Madison, WI, USA, 1969; pp. $1-10$.

26. Webb, E.; Pearman, G.; Leuning, R. Correction of flux measurements for density effects due to heat and water vapour transfer. Q. J. R. Meteorol. Soc. 1980, 106, 85-100. [CrossRef]

27. Dold, C.; Büyükcangaz, H.; Rondinelli, W.; Prueger, J.; Sauer, T.; Hatfield, J. Long-term carbon uptake of agro-ecosystems in the Midwest. Agric. For. Meteorol. 2017, 232, 128-140. [CrossRef]

28. Hernandez-Ramirez, G.; Hatfield, J.L.; Parkin, T.B.; Sauer, T.J.; Prueger, J.H. Carbon dioxide fluxes in corn-soybean rotation in the midwestern U.S.: Inter- and intra-annual variations, and biophysical controls. Agric. For. Meteorol. 2011, 151, 1831-1842. [CrossRef]

29. Baker, J.; Griffis, T. Examining strategies to improve the carbon balance of corn/soybean agriculture using eddy covariance and mass balance techniques. Agric. For. Meteorol. 2005, 128, 163-177. [CrossRef]

30. Hernandez-Ramirez, G.; Hatfield, J.L.; Prueger, J.H.; Sauer, T.J. Energy balance and turbulent flux partitioning in a corn-soybean rotation in the Midwestern US. Theor. Appl. Climatol. 2010, 100, 79-92. [CrossRef]

31. Reichstein, M.; Falge, E.; Baldocchi, D.; Papale, D.; Aubinet, M.; Berbigier, P.; Bernhofer, C.; Buchmann, N.; Gilmanov, T.; Granier, A.; et al. On the separation of net ecosystem exchange into assimilation and ecosystem respiration: Review and improved algorithm. Glob. Chang. Boil. 2005, 11, 1424-1439. [CrossRef]

32. Gilmanov, T.; Soussana, J.-F.; Aires, L.M.I.; Allard, V.; Ammann, C.; Balzarolo, M.; Barcza, Z.; Bernhofer, C.; Campbell, C.; Cernusca, A.; et al. Partitioning European grassland net ecosystem $\mathrm{CO}_{2}$ exchange into gross primary productivity and ecosystem respiration using light response function analysis. Agric. Ecosyst. Environ. 2007, 121, 93-120. [CrossRef]

33. Campbell, G.S.; Norman, J.M. An Introduction to Environmental Biophysics; Springer Science and Business Media LLC: New York, NY, USA, 1998; p. 286.

34. Hatfield, J.L. Radiation Use Efficiency: Evaluation of Cropping and Management Systems. Agron. J. 2014, 106, 1820. [CrossRef]

35. Hatfield, J.L.; Prueger, J.H. Value of Using Different Vegetative Indices to Quantify Agricultural Crop Characteristics at Different Growth Stages under Varying Management Practices. Remote Sens. 2010, 2, 562-578. [CrossRef]

36. Abendroth, L.J.; Elmore, R.W.; Boyer, M.J.; Marlay, S.K. Corn Growth and Development; PMR: Ames, IA, USA, Iowa State University Extension; 2011.

37. Pedersen, P. Soybean Growth and Development; Iowa State University: Ames, IA, USA, 2004.

38. USGS. US Geological Survey, MODIS Products Courtesy of the U.S. Geological Survey. Available online: https://lpdaacsvc.cr.usgs.gov/appeears/ (accessed on 21 March 2019).

39. Myneni, R.; Knyazikhin, Y.; Park, T. MOD15A2H MODIS/Terra Leaf Area Index/FPAR 8-Day L4 Global 500 m SIN Grid V006 [Dataset]. Available online: http://doi.org/10.5067/MODIS/MOD15A2H.006 (accessed on 10 October 2018).

40. Lowe, P.R. An Approximating Polynomial for the Computation of Saturation Vapor Pressure. J. Appl. Meteorol. 1977, 16, 100-103. [CrossRef]

41. R Core Team. The R Foundation for Statistical Computing; The R Foundation: Vienna, Austria, 2014.

42. Friedl, M.; Sulla-Menashe, D. MCD12Q1 MODIS/Terra+ Aqua Land Cover Type Yearly L3 Global 500m SIN Grid V006 [Dataset]. Available online: http://doi.org/10.5067/MODIS/MCD12C1.006 (accessed on 10 October 2018).

43. Pedersen, P.; Lauer, J.G. Response of Soybean Yield Components to Management System and Planting Date. Agron. J. 2004, 96, 1372. [CrossRef]

44. Karlen, D.L.; Kovar, J.L.; Birrell, S.J. Corn Stover Nutrient Removal Estimates for Central Iowa, USA. Sustainability 2015, 7, 8621-8634. [CrossRef]

45. Prince, S.D.; Haskett, J.; Steininger, M.; Strand, H.; Wright, R. Net primary production of US Midwest croplands from agricultural harvest yield data. Ecol. Appl. 2001, 11, 1194-1205. [CrossRef]

46. Bernacchi, C.J.; Hollinger, S.E.; Meyers, T. The conversion of the corn/soybean ecosystem to no-till agriculture may result in a carbon sink. Glob. Chang. Boil. 2005, 11, 1867-1872. [CrossRef]

47. Hatfield, J.L.; Prueger, J.H.; Kustas, W.P. Spatial and Temporal Variation of Energy and Carbon Fluxes in Central Iowa. Agron. J. 2007, 99, 285. [CrossRef] 
48. Sainju, U.M.; Jabro, J.D.; Stevens, W.B. Soil Carbon Dioxide Emission and Carbon Content as Affected by Irrigation, Tillage, Cropping System, and Nitrogen Fertilization. J. Environ. Qual. 2008, 37, 98. [CrossRef] [PubMed]

49. Kanamitsu, M.; Ebisuzaki, W.; Woollen, J.; Yang, S.-K.; Hnilo, J.J.; Fiorino, M.; Potter, G.L. NCEP-DOE AMIP-II Reanalysis (R-2). Bull. Am. Meteorol. Soc. 2002, 83, 1631-1644. [CrossRef]

(C) 2019 by the authors. Licensee MDPI, Basel, Switzerland. This article is an open access article distributed under the terms and conditions of the Creative Commons Attribution (CC BY) license (http://creativecommons.org/licenses/by/4.0/). 